\title{
Challenges for the protection of older persons and their rights during the COVID-19 pandemic
}

\section{Introduction $^{1}$}

The health and economic crisis like no other in the past 100 years that has been caused by coronavirus disease (COVID-19) has thrown socioeconomic inequalities and unequal access to health and social protection services into even sharper relief. It has also posed socioeconomic challenges that expose the most vulnerable groups in the population to even more severe risks and adversities than they were already facing.

One of the most vulnerable groups is older persons, whose quality of life and rights are being directly impacted by the pandemic. Scientific evidence on the evolution of the pandemic and risk factors associated with COVID-19 have shown that people of any age can contract the disease caused by the severe acute respiratory syndrome coronavirus 2 (SARS-CoV-2). However, older persons have a higher probability of severe symptoms, complications and death, especially those aged 80 or over (WHO, 2020a; United Nations, 2020). In addition, studies show that pre-existing chronic or degenerative conditions are also risk factors associated with a higher probability of severe illness and death as a result of COVID-19 (WHO, 2020a), and it is well known that those comorbidities are more frequent among older persons.

Hence the importance of protecting the rights of older persons during this health crisis, for which efforts must be made on two fronts. First, the right to health, which must be for all, without age-based discrimination. Second, the right to life and the right to a dignified old age until the end of one's days.

The shift in the age structure of the population in Latin America and the Caribbean is at very different stages in different parts of the region. The timing and intensity of the ageing process vary from one country to another and that process is still far from reaching the magnitude seen in Europe and other developed countries, where the older age structure and the pattern of contagion concentrated in this group have had much to do with the high mortality observed within a short period. In fact, although the region's population is ageing, today only $13 \%$ of the population is aged 60 or over, far below the figure of $25 \%$ or more in several European countries. The situation across countries is also quite diverse, with some countries at an advanced or very advanced stage in the process, while it is just beginning in others (United Nations, 2019a).

The countries with younger populations are, in most cases, the ones in which the social and economic development process is the least advanced and in which the population faces the greatest structural risks. These countries generally devote less resources to health care and are still in the process of organizing their health care systems. They have less experience in assisting and caring for older adults, and the coverage of their social security and protection systems is more limited and unequal.

Unless otherwise indicated, the cut-off date for the information used to prepare this report is 31 August 2020.
Introduction

A. Sociodemographic vulnerabilities of older persons vis-à-vis COVID-19

B. National and local measures targeting older adults

C. Policy recommendations Bibliography

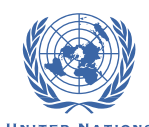

E C LA $\subset$
COVID-19 RESPONSE 
In addition, there is evidence that older people are at a greater risk of infection in the presence of certain combinations of demographic and socioeconomic factors: when there is a high degree of overcrowding within the household, when the percentage of intergenerational households is high, where there is a lack of access to suitable sources of water and sanitation, and where large segments of the population are concentrated in urban areas in substandard housing with insufficient access to basic services.

With respect to this last point, Latin America and the Caribbean is the most urbanized region in the developing world, with around $81 \%$ of its inhabitants living in urban areas (United Nations, 2019a, 2019b, 2019c and 2019d). This urbanization is also highly concentrated in large cities (metropolises of 1 million or more inhabitants, or megapolises of 10 million or more) which are generally marked by strong residential segmentation and social inequality, which is a risk factor for the rapid spread of COVID-19 (United Nations, 2020b). The World Health Organization (WHO, 2020e) notes that population concentration in large cities can enable better access to health care and large cities are better prepared to quickly increase the capacity of their health system but, on the other hand, these potential advantages are partly neutralized by the shortfalls and inequalities typical of the cities in the region.

Inequalities in the sociodemographic and economic spheres and in health determinants build up, heighten each other and interact, giving rise to multiple forms of discrimination that imply differences in the exercise of rights (ECLAC, 2020b). The pandemic's harmful effects on the living conditions of older persons are evident, hence the need to place protection of their rights at the heart of response efforts, in the light of international instruments and agreements such as the Madrid International Plan of Action on Ageing, the San José Charter on the Rights of Older Persons in Latin America and the Caribbean, the Inter-American Convention on Protecting the Human Rights of Older Persons, the Montevideo Consensus on Population and Development, the 2030 Agenda for Sustainable Development and the Asunción Declaration "Building inclusive societies: ageing with dignity and rights".

In this framework, this document offers an analysis of the situation of older persons regarding the possible impacts of COVID-19, taking into consideration factors such as population ageing, health conditions, household arrangements and coresidence, access to basic infrastructure (water and sanitation) and social protection systems. Lastly, it sets forth some actions countries may take to lessen the impact of the pandemic and makes recommendations for tackling the devastating social and economic impact of COVID-19 on older persons, both during the crisis and in the recovery phase, in order to prevent them from being left behind or excluded, taking the various regional and international agreements as a road map.

\section{A. Sociodemographic vulnerabilities of older persons vis-à-vis COVID-19}

The evolution of COVID-19 has shown that the pandemic has a differentiated impact on different people. In this regard, older persons have specific vulnerabilities and, given the heterogeneities within and between countries, it is important to turn a spotlight on those aspects and form an overview of the latest situation. The sociodemographic vulnerabilities dealt with here that affect older persons in particular include the degree of population ageing in the country, given that advanced age is a risk factor; health conditions in terms of chronic illnesses and health determinants associated with greater risk; household arrangements and coresidence, given the physical distancing recommendations; access to basic infrastructure (water and sanitation), which is essential to contain the spread of the virus; and access to social protection systems, which in turn influence health determinants in the population.

The pandemic also affects different territories in different ways. In fact, the health and economic crisis has accentuated vulnerability in Latin America and the Caribbean -a region marked by deep inequality in various dimensions, high levels of poverty and weak social protection and health systems - and has thrown into even sharper relief socioeconomic inequalities and disparities in access to health and social protection services, especially for more vulnerable groups of the population, such as older persons. 
In this context, different international entities and civil society organizations in the region have issued statements and documents referring to older persons and COVID-19, to the effect that States must protect, uphold and promote the right to life of older persons and demand respect for it, regardless of age (Cisternas and Pineda, 2020; Huenchuan, 2020a and 2020b). A brief summary of these calls and statements is given in box 1 on the right to life of older persons and bioethical recommendations during the COVID-19 pandemic.

Box 1

Main calls upon States to ensure the rights of older persons during the COVID-19 pandemic

In late March, the Special Envoy of the Secretary-General on Disability and Accessibility and the Independent Expert on the enjoyment of all human rights by older persons issued a joint statement making a series of bioethical recommendations to States to apply in actions taken during the pandemic. These recommendations included the following: (i) Every person with a disability and every older person infected with COVID-19 has the right to access intensive care units, including mechanical ventilation systems and other life-saving supports, on an equal basis with others. Every person's life has equal value; (ii) Being a person with a disability or an older person will not be a condition or determinant to deny or omit access to intensive care, including mechanical ventilation systems, and all life supports, when required, regardless of health insurance coverage, if any; (iii) The refusal or omission can be qualified as disability discrimination under the Convention on the Rights of Persons with Disabilities (article 11), or age discrimination in old age under the Inter-American Convention on Protecting the Human Rights of Older Persons (article 12); (iv) The person with disability and the older person infected with COVID-19 will always have the right to dignified treatment, autonomy in decision-making, respect for their will, preferences, free and informed consent and the privacy of their personal data; and (v) The person with disability and the older person infected with COVID-19 will have the right to receive all public information about COVID-19 in a timely and accessible manner, using reasonable accommodation, if necessary.

In April 2020, the Inter-American Commission on Human Rights (IACHR), as part of the work of its Rapid and Integrated Response Coordination Unit for the COVID-19 pandemic (SACROI COVID-19), urged States to provide greater protection for older people, who are particularly vulnerable during the pandemic, and to adopt the necessary measures to guarantee their rights in accordance with the Inter-American Convention on Protecting the Human Rights of Older Persons, and the standards and recommendations set out in IACHR Resolution No. 01/20, "The Pandemic and Human Rights in the Americas."

IACHR expressed its deep concern regarding the high rates of infection, hospital admissions, and deaths of older people recorded in the previous month. The Commission urged States to guarantee older persons' right to physical and mental health and adopt the necessary measures to prevent contagion in all areas, particularly in long-term residences, hospitals, and places where people are deprived of their freedom. To that end, States should also prioritize COVID-19 testing for older people. In view of the worsening of this crisis and the ensuing shortages of medical supplies, IACHR also expressed concern that older people were being exposed to a greater degree of discrimination and stigmatization within health services, such as when triaging or assigning respirators and urged States to act to guarantee older persons' right to life, health, and personal integrity and to avoid any form of discrimination on the basis of age or ageism.

Source: Economic Commission for Latin America and the Caribbean (ECLAC), on the basis of Inter-American Commission on Human Rights (IACHR), "IACHR Urges States to Guarantee the Rights of Older People during the COVID-19 Pandemic", Press Release, Washington, D.C., 23 April 2020 [online] https://www.oas.org/en/iachr/media_center/PReleases/2020/088.asp; United Nations, "Joint statement: the right to life of persons with disabilities and older persons infected by COVID-19", New York, 2020 [online] https://www.un.org/development/ desa/disabilities/wp-content/uploads/sites/15/2020/04/Version2-Decl-Estandar-Bioet-Dpcd-ENabril20.pdf.

In the same vein, the Montevideo Consensus on Population and Development, in chapter C, "Ageing, social protection and socioeconomic challenges" emphasizes in priority action 22 the need to "eradicate the multiple forms of discrimination that affect older persons, including all forms of violence against older women and men, taking into account the obligations of States with respect to ageing with dignity and rights". This priority action is highly relevant to the situation faced by older persons during the pandemic in our region. Priority action 24 calls upon States to "give the highest priority to older persons in plans for disaster prevention, mitigation and relief, including disaster preparedness, relief worker training on emergency prevention and response and the availability of goods and services". This priority action of the Consensus is highly trenchant and germane during the current health emergency in the region, and it backs up the provisions of the Inter-American Convention on Protecting the Human Rights of Older Persons in this regard. Furthermore, the 2030 Agenda and Sustainable 
Development Goal 3 stipulate the obligation to ensure healthy lives and promote well-being for all at all ages. The pandemic is a watershed moment that requires health emergency preparedness on the part of States, but it also obliges them to devote resources to proper management of the situation, especially with regard to older persons.

\section{Population ageing and the differentiated impacts of COVID-19 by age and sex}

Latin America and the Caribbean has around 654 million inhabitants, just over half of whom are women. Of the population, $24 \%$ is aged under 15 and older persons (those aged 60 or over) make up 13\%. Projections for 2050 indicate that older persons will represent almost $25 \%$ of the region's population, while the percentage aged under 15 will fall to $17 \%$. The number of people aged 60 or over will exceed the under-15s for the first time around 2038 (United Nations, 2019a).

Another major trend to consider is the pattern of ageing among older persons, with a significant rise in the number reaching advanced ages (see figure 1). The group of more elderly persons (80 and over), which currently represents 1.9\% of the total population (some 12.4 million), will grow particularly quickly and is projected to exceed 41 million within the next 30 years (United Nations, 2019a). This trend is significant because that group generally has very different needs and capacities than other age groups. In addition, women, who have a longer life expectancy and higher survival rate than men, are overrepresented among older persons, especially in the over-80 age group, which has important implications for health and care policies and actions. Today, there are 81 men for every 100 women in the group aged 60 and over in the region, compared to only 64 men per 100 women in the group aged 80 and over.

Figure 1

Latin America and the Caribbean: evolution of the population of older persons, by sex, 1960-2100

(Percentages)

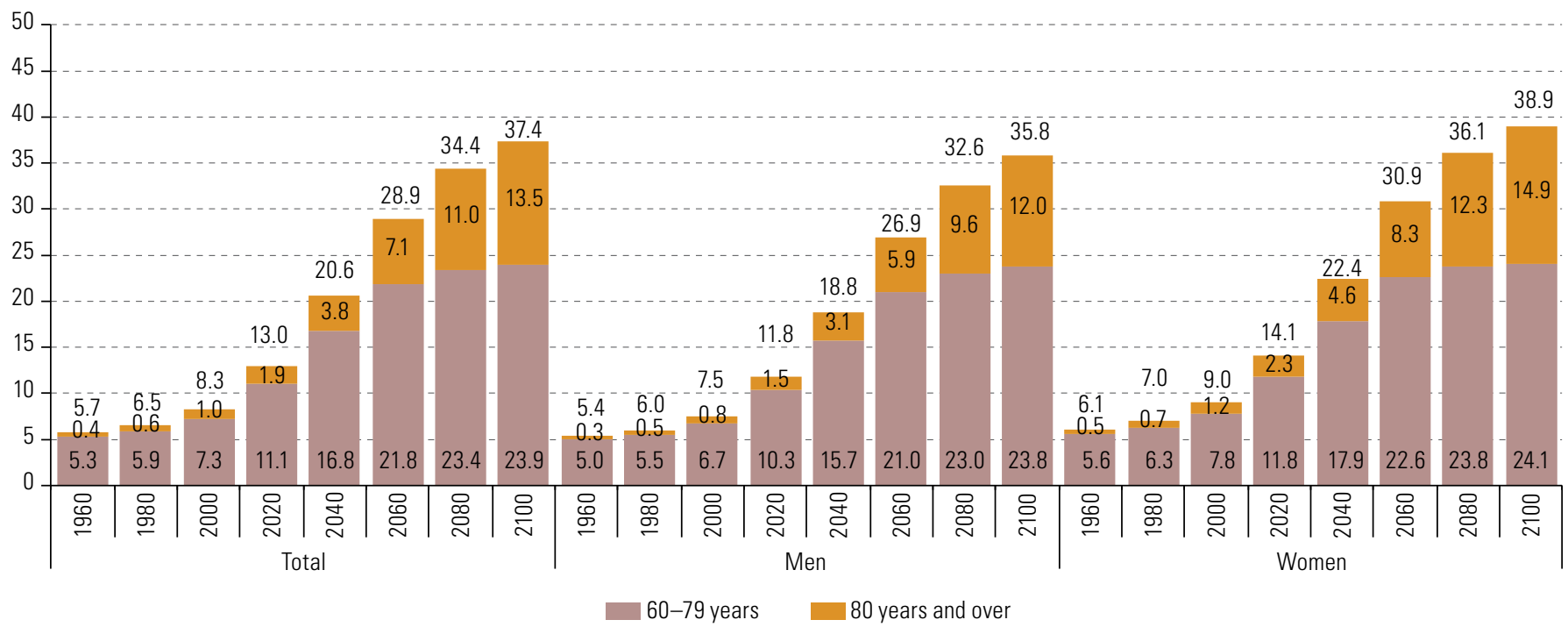

Source: United Nations, World Population Prospects: The 2019 Revision, New York, 2019.

The great variety in demographic processes, expressed in terms of the percentage of older persons in the population and differentials by sex in the region are depicted in figure 2 . In countries such as Cuba, Uruguay, Chile and Argentina, the ageing process has reached quite an advanced stage in 2020, with a fifth of the population aged 60 or over and with significant differentials by sex. At the other extreme, with a very incipient ageing process behind the average for the region, are some Central American and Caribbean countries, including Guatemala, Honduras, Haiti and Nicaragua. They all show major differentials by sex, with more women among the very elderly. 
Figure 2

Latin America and the Caribbean: population aged 60-79 years and 80 years and over, by sex, 2020

(Percentages)

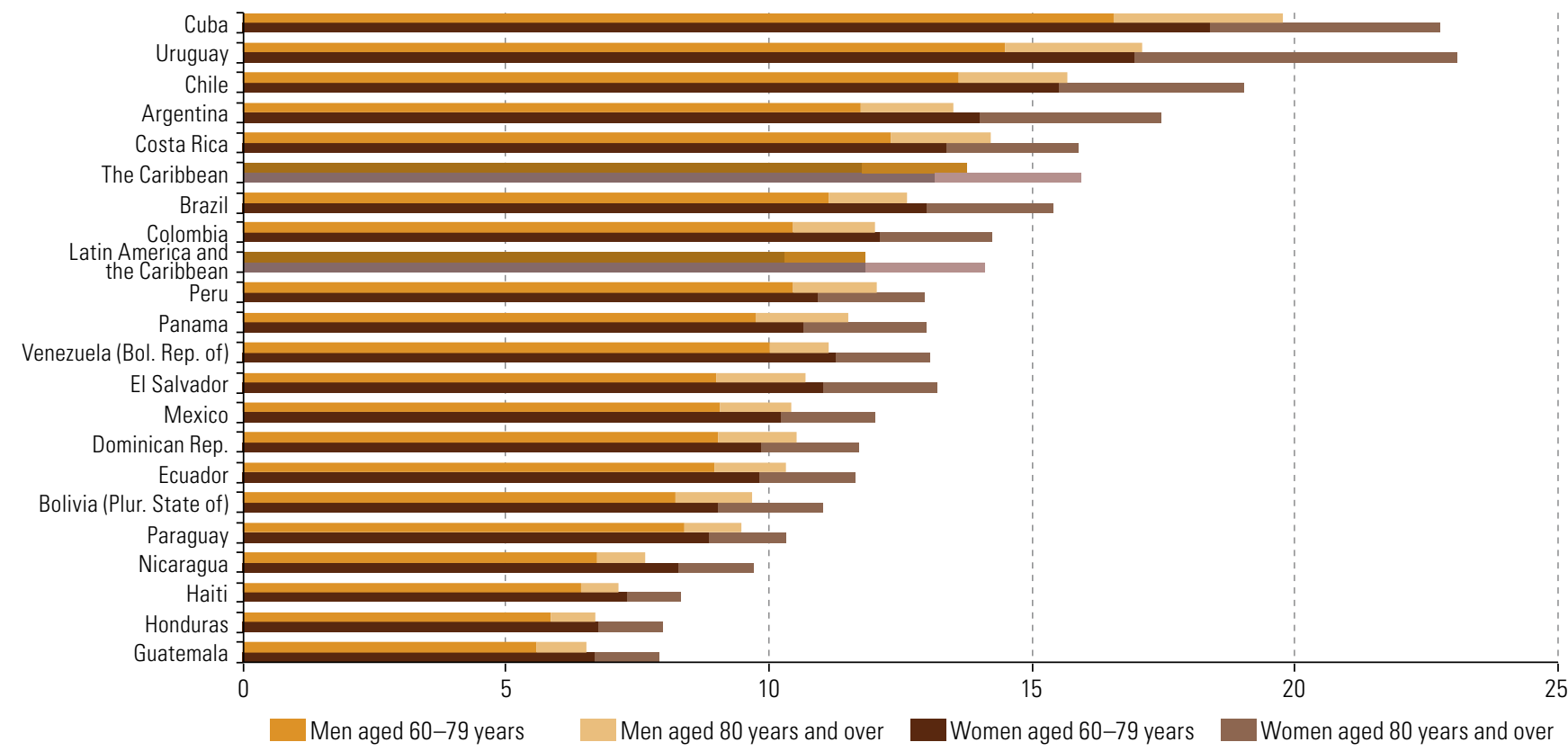

Source: United Nations, World Population Prospects: The 2019 Revision, New York, 2019.

The World Health Organization (WHO) described the pandemic as having three defining characteristics that make it unique and devastating: (i) the speed and scale with which it has spread; (ii) the severity of the disease, with a high rate of fatality and mortality, especially in older persons; and (iii) its power to cause societal and economic disruption owing to the measures needed to contain the virus (WHO, 2020a)

Accordingly, WHO proposed that countries "find, test, isolate and care for cases and quarantine contacts to control transmission" (WHO, 2020a, p. 8). Among other things, the measures taken, the timing of decisions and the degree of cooperation of the population meant that the evolution of the pandemic, still ongoing, was different in each country.

Information on the number of people infected and deaths by age and sex is essential, because it has been known from the start, from the way the pandemic developed in China, Italy and Spain, that older persons are more likely to suffer severe illness or die as a result of COVID-19. One hundred days after WHO was apprised of the first case, the Organization noted that although the disease spread differently in different countries, the average fatality rate could exceed 3\% and rose with age to reach 15\% in patients aged 80 or above (WHO, 2020a).

After the outbreak, some authors researched the impacts of infection in populations with different structures by age or sex, using data from China and Italy, the first two countries badly affected by the pandemic (Dowd and others, 2020; Promislow, 2020). The data show that the risk of severe illness and death in those two countries was higher among older persons and higher still among men than women. Dowd and others (2020) emphasized that the analysis pointed to the importance of taking these findings into account in strategies against COVID-19, owing to the biological mechanisms of ageing which are often accompanied by comorbidities, another risk factor closely associated with more severe cases. Guilmoto (2020) broadens the analysis on the possible effects of age and sex on the evolution of COVID-19, using data from Western Europe and the United States. Guilmoto draws attention to significant underreporting evident in death records and differentials by several factors (such as age), linked mainly to deaths recorded at home, as occurred in Italy. One important conclusion is that the age gradient of COVID-19 mortality is steeper than for overall mortality, resulting in a higher concentration of deaths among older persons (Guilmoto, 2020, p. 11). 
At this time, systematized information by age and sex on COVID-19 confirmed cases and deaths in the Latin American and Caribbean countries is not sufficient or complete enough to confirm whether the findings from other regions apply here as well. ${ }^{2}$ Despite the uncertainties and shortfalls in the data, it is essential to map out, in the short term, a picture of each population group's biological response to the disease and the resulting medium- and long-term implications in terms of ensuring that measures taken against the pandemic are effective and respect the rights of all, especially the right to a healthy and dignified life.

The data from some countries confirm the profile of a higher percentage of deaths among older persons (see table 1), even though the countries' measurements do not all use the same age groups or the same distribution by sex, and do not all have the same accuracy in diagnosis and classification of COVID-19 deaths. There are differentiated trends with respect to those seen in Europe and the United States, which allow for some comparisons to be made. In Latin America, mortality has been less concentrated among older persons, especially the much older age group (80 and over), partly because of the region's younger age structure. In the more developed countries, persons aged 60 and over represented over $95 \%$ of deaths, and in some cases over half of deaths occurred among those aged over 80

Table 1

Distribution of COVID-19 deaths by age group and by country

(Percentages and numbers)

\begin{tabular}{|c|c|c|c|c|c|}
\hline & 60 and over & 70 and over & 80 and over & Deaths & Date \\
\hline Brazila & 74,9 & 52,3 & 26,8 & 121381 & $31 / 08 / 2020$ \\
\hline Mexico & 59,1 & 31,5 & 10,6 & 64414 & $31 / 08 / 2020$ \\
\hline Peru & 69,5 & 41,4 & 16,9 & 28994 & $31 / 08 / 2020$ \\
\hline Chile & 84,0 & 62,6 & 34,5 & 11321 & 01/09/2020 \\
\hline Colombia & 73,6 & 50,6 & 25,5 & 19663 & $31 / 08 / 2020$ \\
\hline Spain & 94,2 & 83,2 & 54,6 & 29152 & 01/09/2020 \\
\hline Italy ${ }^{c}$ & 95,4 & 85,3 & 59,0 & 35944 & $31 / 08 / 2020$ \\
\hline \multirow[t]{2}{*}{ Sweden } & 96,0 & 89,1 & 67,5 & 5813 & 01/09/2020 \\
\hline & 65 and over & 75 and over & 85 and over & & \\
\hline Ecuador $^{d}$ & 59,1 & n.d. & n.d. & 9911 & $22 / 08 / 2020$ \\
\hline United Kingdom & 89,4 & 74,6 & 42,3 & 52026 & $14 / 08 / 2020$ \\
\hline United States & 79,2 & 57,9 & 31,5 & 164276 & 26/08/2020 \\
\hline
\end{tabular}

Source: Economic Commission for Latin America and the Caribbean (ECLAC), on the basis of official data from the respective countries

a Up to 24 August 2020,143,149 deaths were recorded with severe acute respiratory syndrome as the cause.

${ }^{\mathrm{b}}$ The Ministry of Health of Spain stopped publishing reports on the number of deaths by age group on 29 May 2020 (report no. 120), so the percentages correspond to that report and only the total figure reflects the situation at 1 September 2020

' The last report with disaggregated death data was published on 22 July 2020 . The date shown is valid for total deaths.

d Deaths correspond to the total number in which COVID-19 was confirmed or suspected, according to the government's latest epidemiologic bulletin.

With respect to the comparison by sex, although not all the countries issue these data fully, and the pandemic is still ongoing, preliminary information shows that older persons, both men and women, are showing higher levels of mortality from COVID-19 than the younger population.

Analysis of the data available for some countries, such as Brazil, Mexico and Peru, shows that many more men than women of all ages lost their lives to COVID-19, in fact, two or three times more, depending on age (see figure 3). The ratios are highest in Peru. One of the explanations for this could be higher rates of infection among men, who may be more exposed, and also risk factors associated with comorbidities that are differentiated

2 There are very good examples of data dissemination in epidemiological surveillance systems and knowledge and technology available in the region. Among other things, however, there is a lack of systematization, organization and standardization of the concepts used for confirmed and suspected cases 
by sex, which could lead to women being less likely to suffer severe illness than men.

The exception to this pattern occurred in women under age 19 and much older women

(aged 90 and over) in Brazil, who showed higher death rates than men

\section{Figure 3}

Brazil (24 August), Mexico and Peru (31 August): number of men per 100 women among COVID-19 deaths, by age group, 2020

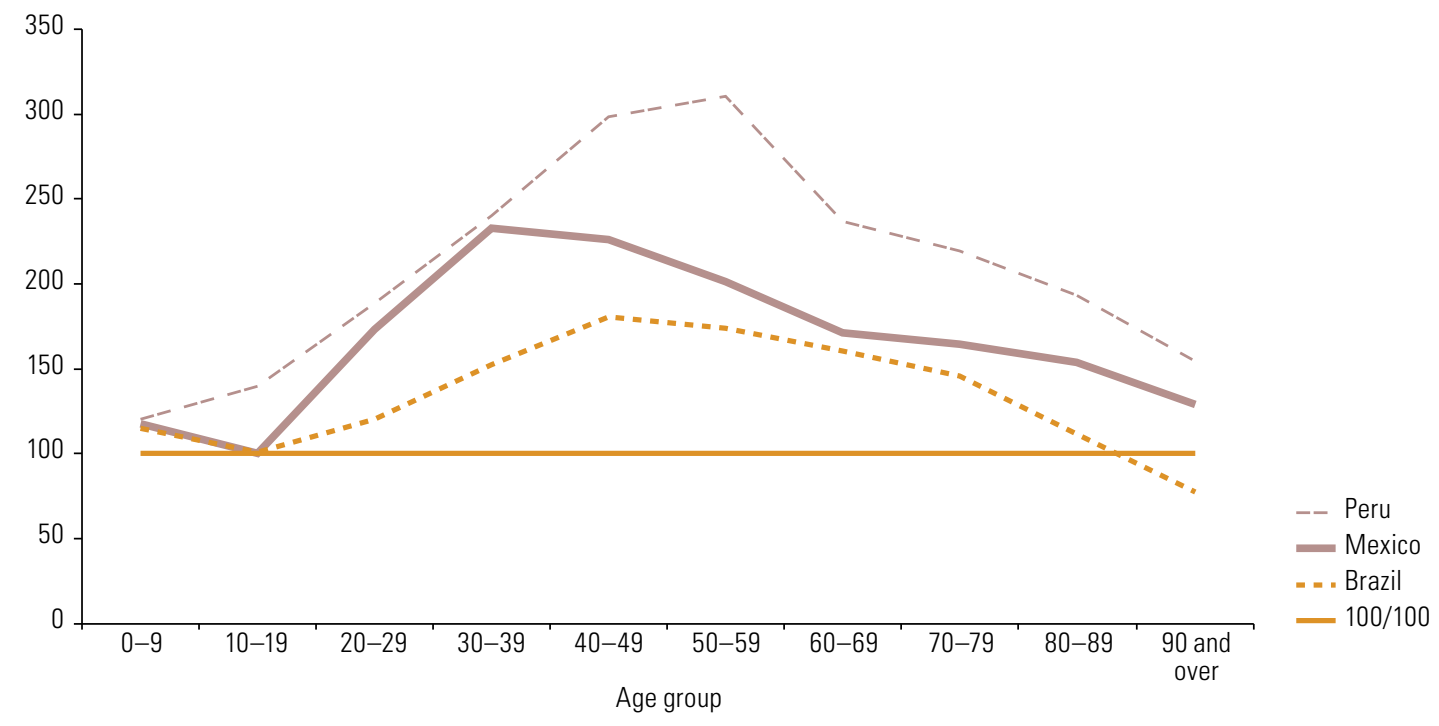

Source: Economic Commission for Latin America and the Caribbean (ECLAC), on the basis of official data from the respective countries.

\section{Health conditions of older persons and differential effects of COVID-19 owing to morbidity and other factors}

In addition to age, another risk factor known from the experiences of countries at more advanced stages of the pandemic, and as noted earlier, is the pre-existence of chronic diseases and multiple morbidities. ${ }^{3}$

The pandemic found many countries with great weaknesses in their health systems. A recent report by the Economic Commission for Latin America and the Caribbean (ECLAC) and the Pan American Health Organization (PAHO) notes that these systems in the region are "underfinanced, segmented, and fragmented, which results in significant barriers to access" (ECLAC/PAHO, 2020, p. 3). They all had to quickly resolve possible lack of supplies and health personnel, seeking to prevent health systems from collapsing. In this context, health-care plans to address the most critical moments of the pandemic had to be drawn up alongside the attempt to contain the spread of the virus through national territories.

In the great majority of the region's countries, older persons and the very elderly suffer more from cerebrovascular accidents and coronary heart disease. To weigh the risks for the population, rather than the relative distribution of disease, it is important to ascertain the percentage of the population that has those diseases, since that group will be more likely to need hospitalization and mechanical ventilation.

By way of example, table 2 shows the percentage of persons aged over 60 , by sex, for three groups of diseases that have been identified as carrying the greatest risk in relation to COVID-19: cerebrovascular disease (cerebrovascular accidents/strokes and coronary heart disease), chronic respiratory conditions and diabetes.

According to WHO (2020g), people with cardiovascular disease (hypertension or those who have had or are at risk of having a heart attack or stroke), chronic obstructive pulmonary disease, diabetes and cancer seem to be more vulnerable to becoming severely ill with the virus. 
Table 2

Latin America and the Caribbean: older persons (60 and over), by selected chronic disease and sex, around 2017 (Percentages)

\begin{tabular}{|c|c|c|c|c|c|c|c|c|c|}
\hline & \multicolumn{3}{|c|}{$\begin{array}{l}\text { Cerebrovascular disease } \\
\text { (cerebrovascular accidents } \\
\text { and coronary heart disease) }\end{array}$} & \multicolumn{3}{|c|}{ Chronic respiratory conditions } & \multicolumn{3}{|c|}{ Diabetes } \\
\hline & Total & Men & Women & Total & Men & Women & Total & Men & Women \\
\hline & \multicolumn{9}{|c|}{60 and over } \\
\hline Argentina & 32.8 & 35.5 & 30.7 & 20.7 & 27.9 & 15.6 & 16.3 & 17.9 & 15.1 \\
\hline Bahamas & 29.5 & 30.8 & 28.6 & 17.6 & 21.4 & 14.6 & 22.5 & 23.6 & 21.6 \\
\hline Barbados & 33.4 & 34.6 & 32.4 & 16.7 & 20.2 & 14.0 & 27.9 & 26.7 & 28.8 \\
\hline Belize & 29.1 & 30.4 & 27.9 & 19.4 & 23.4 & 15.4 & 28.1 & 26.3 & 29.8 \\
\hline Bolivia (Plurinational State of) & 26.8 & 27.5 & 26.2 & 20.0 & 23.7 & 16.7 & 15.5 & 16.3 & 14.8 \\
\hline Brazil & 30.1 & 34.3 & 26.7 & 22.2 & 27.9 & 17.8 & 12.0 & 12.3 & 11.7 \\
\hline Chile & 31.5 & 33.8 & 29.7 & 18.7 & 22.9 & 15.3 & 13.7 & 14.7 & 12.9 \\
\hline Colombia & 25.8 & 26.2 & 25.4 & 23.8 & 28.3 & 20.0 & 13.4 & 14.8 & 12.3 \\
\hline Costa Rica & 26.5 & 27.0 & 26.1 & 22.2 & 25.8 & 18.9 & 13.6 & 15.2 & 12.2 \\
\hline Dominican Republic & 30.8 & 32.5 & 29.2 & 17.5 & 20.5 & 14.8 & 14.0 & 15.0 & 13.1 \\
\hline Ecuador & 27.1 & 27.6 & 26.6 & 15.0 & 18.7 & 11.8 & 15.0 & 15.4 & 14.6 \\
\hline El Salvador & 26.1 & 26.7 & 25.7 & 19.6 & 22.7 & 17.2 & 18.2 & 19.4 & 17.3 \\
\hline Guatemala & 27.1 & 28.0 & 26.3 & 18.9 & 22.9 & 15.5 & 23.0 & 25.3 & 21.2 \\
\hline Guyana & 30.2 & 32.0 & 28.6 & 17.8 & 21.1 & 14.8 & 31.2 & 30.0 & 32.2 \\
\hline Haiti & 28.8 & 30.5 & 27.4 & 18.4 & 21.1 & 16.2 & 20.7 & 17.4 & 23.5 \\
\hline Honduras & 24.7 & 26.9 & 22.9 & 23.0 & 25.5 & 20.9 & 17.3 & 18.0 & 16.7 \\
\hline Jamaica & 31.0 & 32.3 & 29.8 & 18.9 & 23.5 & 14.7 & 34.7 & 31.1 & 38.0 \\
\hline Mexico & 27.2 & 27.2 & 27.2 & 21.4 & 26.4 & 17.1 & 30.2 & 33.8 & 27.1 \\
\hline Paraguay & 31.3 & 35.0 & 27.8 & 19.4 & 23.9 & 15.1 & 21.6 & 20.3 & 22.8 \\
\hline Peru & 25.2 & 25.6 & 24.8 & 16.8 & 20.0 & 14.0 & 11.0 & 12.2 & 9.9 \\
\hline Suriname & 31.9 & 34.1 & 30.2 & 20.4 & 24.8 & 17.1 & 26.0 & 28.9 & 23.8 \\
\hline Trinidad and Tobago & 32.0 & 33.5 & 30.8 & 20.2 & 25.5 & 15.8 & 45.0 & 54.4 & 37.3 \\
\hline Uruguay & 34.1 & 36.1 & 32.7 & 23.8 & 33.5 & 17.2 & 12.3 & 13.4 & 11.5 \\
\hline
\end{tabular}

Source: Inter-American Development Bank (IDB), "Indicators: panorama of aging and long-term care", 2020 [online] https://www.iadb.org/ en/panorama/indicators; Institute for Health Metrics and Evaluation (IHME), GBD Results Tool, Seattle, 2017 [online database] http://ghdx. healthdata.org/gbd-results-tool.

According to the data presented, between a quarter and a third of those aged 60 and over have been diagnosed with cerebrovascular accidents and coronary heart disease. Men show a higher incidence than women, which places them at greater risk of severe illness in the event of contracting COVID-19. In the case of chronic respiratory conditions, the differences by sex are significant in most countries, with men more affected.

Diabetes in older persons is the condition that shows most variation between countries, with figures ranging from a low of $11 \%$ to a high of $45 \%$. In some countries, older women are more affected by the disease, although the gender differentials show that women tend to take better care in terms of controlling it. Be this as it may, more recent data will be needed as well as data on disease control in order to draw a more accurate comparison. 
Other risk factors that make people more vulnerable to falling severely ill with COVID-19 are obesity, smoking and other conditions that increase the need for oxygen or reduce the body's ability to use it properly (WHO, 2020a). Some countries have data on these conditions and figure 4 shows both the broad variation between the countries of the region and the large differential by sex and age in the prevalence of obesity and tobacco use.

Figure 4

Latin America (5 countries): persons aged 60 and over and 80 and over, by sex and specific risk factor (obesity and smoking) (Percentages)

\section{A. Obesity}

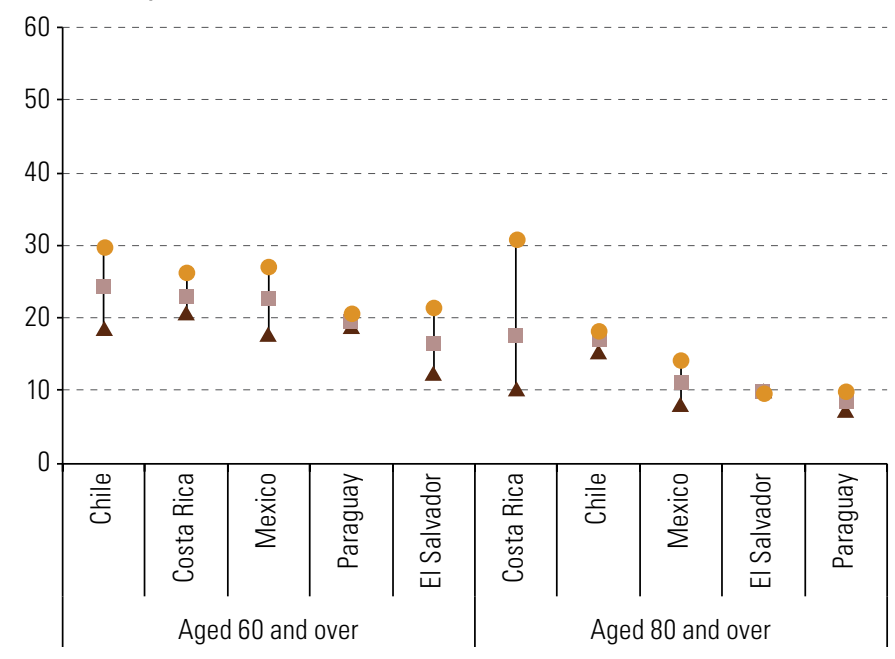

Women
B. Tobacco use

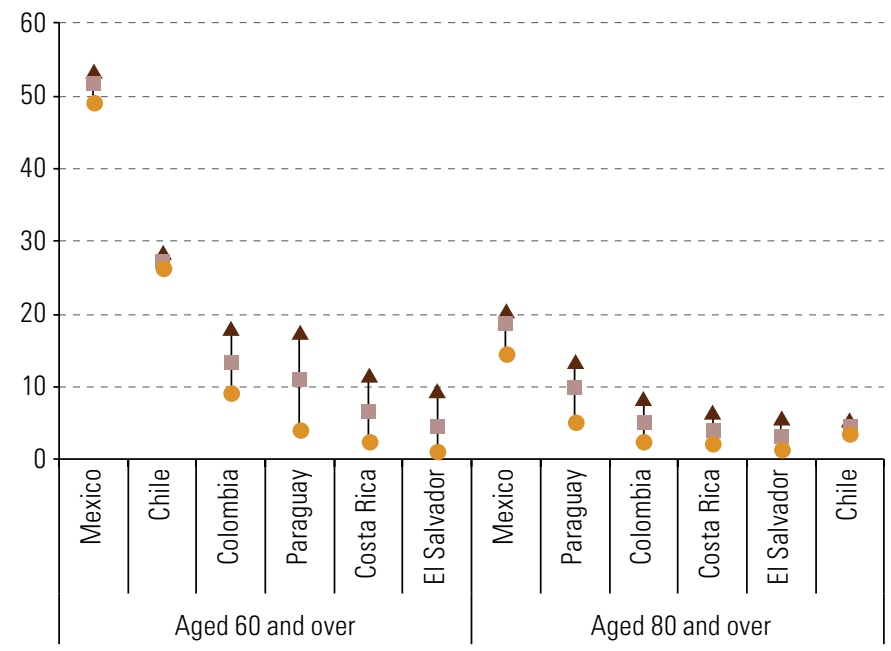

Men Total

Source: Inter-American Development Bank (IDB), "Indicators: panorama of aging and long-term care", 2020 [online] https://www.iadb.org/en/ panorama/indicators; and surveys from the respective countries.

In relation to obesity, around a quarter of those aged 60 and over were classified as obese in some countries, although the proportion is smaller in the age group over 80. However, in practically all the countries the obese group has a higher percentage of women than men. The situation by sex is the reverse for smokers, although the prevalence of smoking is higher for older and much older men.

The data on pre-existing morbidities among those infected with COVID-19 in the countries of the region are still very scarce. Since the first news of the disease became known, the severity and mortality of COVID-19 were associated with prior chronic conditions. Among the most common were cardiovascular disease, diabetes, chronic respiratory conditions and hypertension -often with more than one of these in the most severe cases - although people with generally good health also presented severe cases.

Inequalities in health conditions and health fragilities in this population, with a different epidemiological profile to that of developed countries, combined with issues of access and service quality in developing countries' health systems, could further increase the severity and fatality rate of COVID-19 infection among older persons in the region.

\section{Older persons with disabilities}

As discussed in the preceding section, the comorbidities that are common among older persons can increase the severity of the coronavirus disease and the probability of dying from it. By the same token, the different types of disabilities that older adults may have may also influence how likely they are to become infected. And if older persons with disabilities do become infected, then, depending on the type of disability 
concerned, their symptoms may be worse. WHO has stated that disabilities that make it harder for older persons to engage in basic types of personal hygiene are among the factors that may put them at greater risk of contracting COVID-19. For example, it is hard for people to wash their hands if they have a disability that hinders them from rubbing their hands together or if a person with reduced mobility cannot reach the washbasin. As another example, blind persons or persons with impaired vision who need to touch certain objects in order to gather information about their surroundings may be more exposed to contagion, as well as having greater difficulty in obtaining public health information (WHO, 2020f).

Older persons with disabilities who also have comorbidities may run a greater risk of having a very serious case of COVID-19 if they contract the disease. WHO has said that the main reason for this is that "COVID-19 exacerbates existing health conditions, particularly those related to respiratory function, immune system function, heart disease or diabetes"; in addition, older persons with disabilities may encounter greater "barriers to accessing health care" (WHO, 2020f).

Overall, persons with disabilities account for between $4 \%$ and $24 \%$ of the population in the region, according to census data (González and Stang, 2014). These figures have risen over the last decade as data collection ${ }^{4}$ from various sources, especially censuses and surveys, has improved. The percentage of the population with disabilities climbs with age, and the percentage of older adults with disabilities is therefore higher.

An analysis of the census results for eight countries of the region that conducted their censuses during the first five years of the 2010s indicates that 41 out of every 100 older persons had some form of disability. Some of the highest figures are for Brazil (over $60 \%$ ) and the Dominican Republic and Uruguay (45\%). The rate of disability is higher among women than men (43\% versus 38.8\%) (Huenchuan, 2018).

The data from more recent censuses reflect a very similar trend: the percentage of persons with disabilities increases with age, and a slightly larger proportion of women than men have a disability. Around 14\% of persons aged 60 and over in Guatemala and Colombia have some sort of disability, while the figure for older persons in Peru is $35 \%$. At 80 years of age and over, the prevalence of disability rises further, to around $30 \%$ in Guatemala and Colombia and 58\% in Peru (see table 3). In all the countries shown in table 3 , the percentages for women are slightly higher than they are for men.

Table 3

Guatemala, Colombia and Peru: percentage of persons with disabilities, by age group and sex, according to 2010-round censuses

\begin{tabular}{|c|c|c|c|c|c|c|c|c|c|}
\hline \multirow{2}{*}{ Countries } & \multicolumn{3}{|c|}{ Men } & \multicolumn{3}{|c|}{ Women } & \multicolumn{3}{|c|}{ Both sexes } \\
\hline & $60-79$ & 80 and over & 60 and over & $60-79$ & 80 and over & 60 and over & $60-79$ & 80 and over & 60 and over \\
\hline Guatemala & 10.0 & 30.8 & 13.0 & 10.9 & 31.6 & 14.0 & 10.5 & 31.2 & 13.5 \\
\hline Colombia & 11.0 & 28.0 & 13.4 & 11.5 & 30.3 & 14.6 & 11.3 & 29.4 & 14.1 \\
\hline Peru & 28.0 & 57.0 & 32.5 & 33.7 & 58.3 & 38.0 & 31.0 & 57.7 & 35.4 \\
\hline
\end{tabular}

Source: Economic Commission for Latin America and the Caribbean (ECLAC), on the basis of population and housing censuses of the respective countries.

In accordance with international and national recommendations for increasing the accuracy of data on disability, some Latin American countries switched over from a biomedical to a biosocial or social perspective in framing the questions about people's limitations that were asked on population census forms in the 2010 round. Most of the questions on disability in these censuses referred to limitations of sight, hearing, mobility or walking, memory or the ability to concentrate, the performance of personal hygiene routines and communication. The data obtained by these means no doubt continue to suffer from some shortcomings, but this information is still the best available source of statistics on the percentage of persons with disabilities in the countries of the region and in certain specific groups, such as, in this case, older adults. 
Older adults with disabilities have COVID-specific barriers to surmount as well. In most cases, the orders given to the population to remain home in order to avoid contracting the disease have not taken their needs into consideration, thereby creating new risks in terms of their autonomy, health and life (OHCHR, 2020). Persons that require aid (whether provided formally or informally by family members or friends) to carry out their daily affairs have found themselves without such assistance during the pandemic owing to quarantine and social distancing restrictions on movement within a country's borders. This places older persons with disabilities at a greater risk of going without food, essential goods and medications. This situation may oblige them to go out on their own (if they can) to obtain basic inputs, which places them at greater risk of contagion. The lack of the types of assistance which they had formerly been receiving may also interfere with basic daily activities necessary for their subsistence such as bathing, cooking or eating (OHCHR, 2020).

Another difficulty that has arisen for older adults with disabilities during this health emergency has to do with access to public information about the measures being taken to combat COVID-19 because that information is not disseminated on a systematic basis in accessible formats (e.g. sign-language interpretation, subtitles, easy-read formats, etc.). This hinders their access to the information that they need in order to take appropriate protective measures and thus may increase the likelihood of contagion.

Aggregate data at the country level often conceals sharp differences at smaller geographical scales, however, and this is illustrated by the figures for the three countries for which recent census information on persons with disabilities is available. An analysis based on smaller administrative divisions (municipalities in Colombia and Guatemala, districts in Peru) shows up significant differences.

Map 1 shows the percentages of persons aged 80 and over who have disabilities. In Guatemala (see map 1A), over $50 \%$ of persons above 80 years of age in the municipalities of Usumatlán, San José La Arada, Santa Apolonia, Patzité, Santa Cruz La Laguna, Santa Catarina Mita and San Raymundo have disabilities; in Colombia (see map 1B), there are 322 municipalities in which more than $50 \%$ of persons over 80 years of age have disabilities, with some of the highest figures being in San Juanito (100\%) in Meta Department, Puerto Alegría (100\%) in Amazonas Department, Pana (83\%) in Guainia, El Tablón de Gomez (77.7\%) Nariño Department and Mologavita (75\%) in Santander. In Peru (see map 1C), 1,403 districts out of a total of 1,876 have populations in which more than $50 \%$ of persons aged 80 and over have disabilities, including, most notably, Recta (100\%) in Amazonas Department, Soplin (100\%) in Loreto Department, Pararca (96.2\%) in the Department of Ayacucho, Quilahuani (95.5\%) in Tacna and Masma Chicche (95\%) in Junín.

Persons with disabilities who are 80 years of age or more are often dependent on assistance and cannot live on their own. Many of them are bedridden and require care throughout the day and therefore must have daily caregivers either in their homes or in long-stay care facilities. It is therefore important to have information at the local level on how many people are in this kind of situation and their locations so that the appropriate actions can be taken where they are needed and support for older adults and their families can be properly organized.

Local government authorities are in direct contact with residents and are the ones who receive their requests for health- and care-related support, such as assistance with house calls for older persons who are bedridden, transfers to emergency primary health facilities, medical check-ups or the delivery of medications. Requests for financial assistance are also made for out-of-pocket prescription drug expenses, special food needs and subsidies for essential services. The health emergency has exacerbated existing social and economic problems at the household level, as the accompanying economic crisis has driven up unemployment and monetary poverty sharply in all the countries. Local governments must therefore channel these demands and strive to manage their resources in a way that will allow them to meet these demands, ensure universal accessibility rights in cities and other human settlements and ensure access to health and economic assistance for persons living in poverty while taking local realities and the needs and proposals of the population into account (Cisternas and Pineda, 2020). 


\section{Map 1}

Guatemala, Colombia and Peru: persons aged 80 and over with disabilities, by small administrative divisions, based on censuses from the 2010 round

(Percentages)

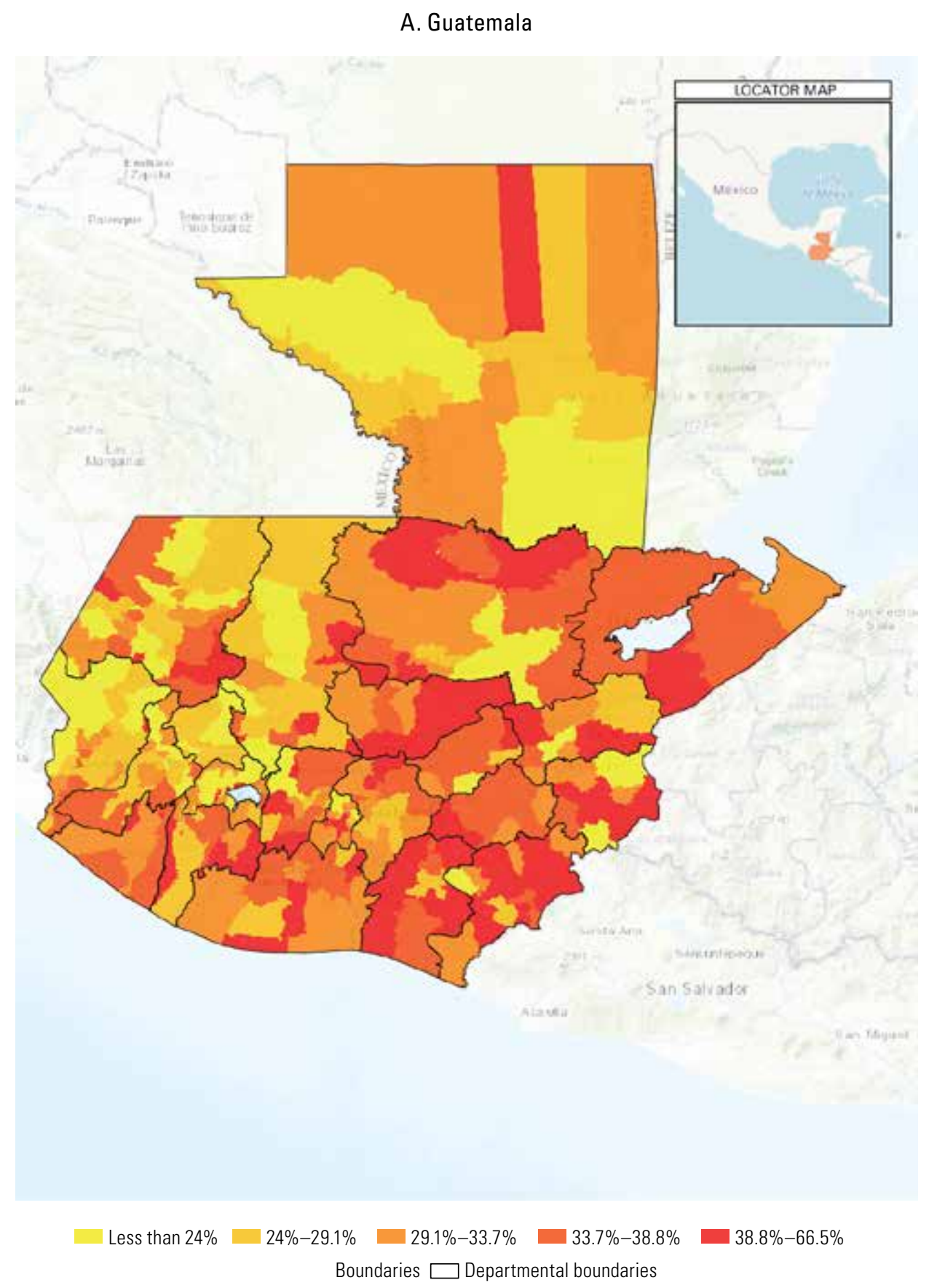


B. Colombia

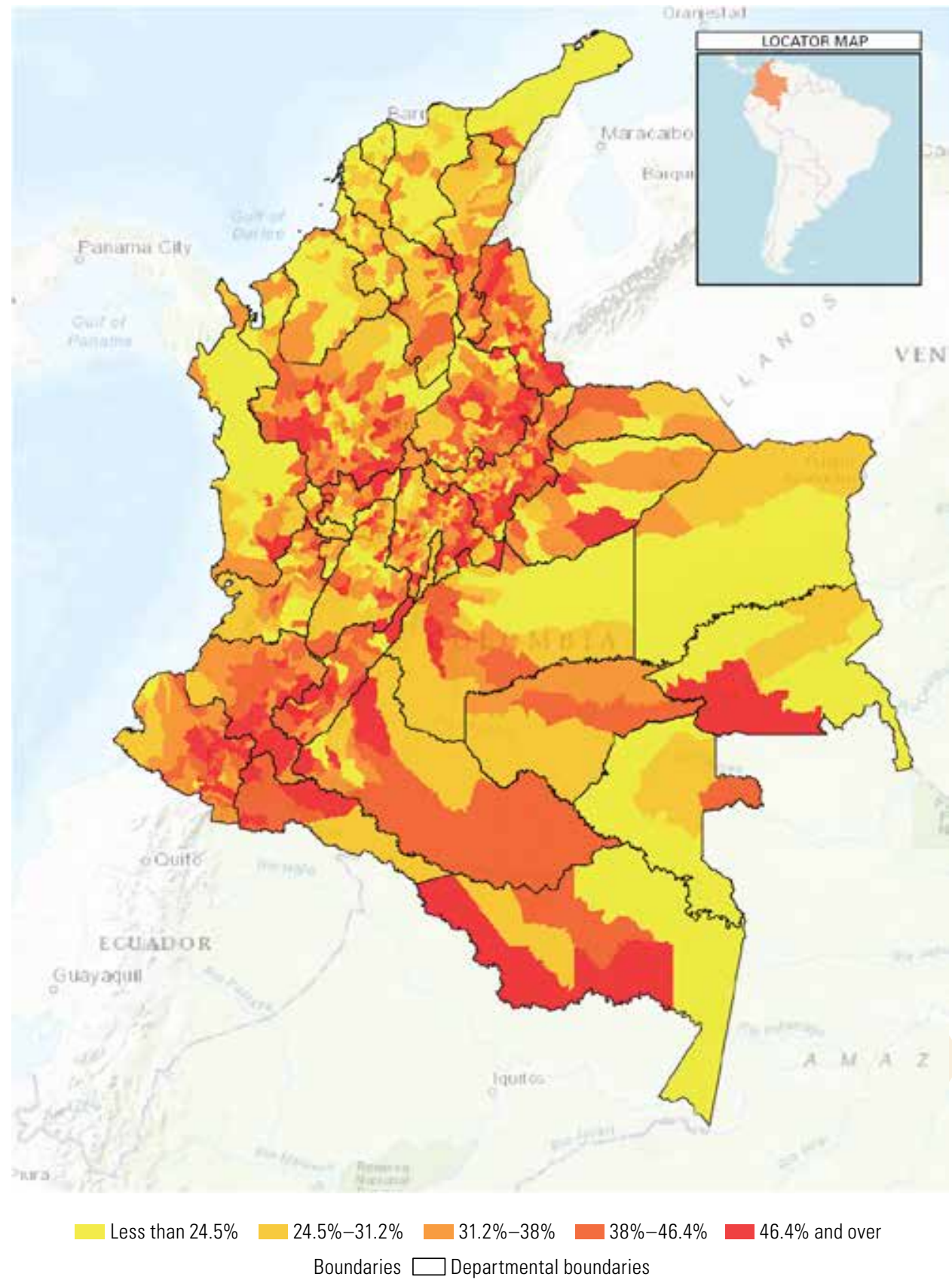


Map 1 (concluded)

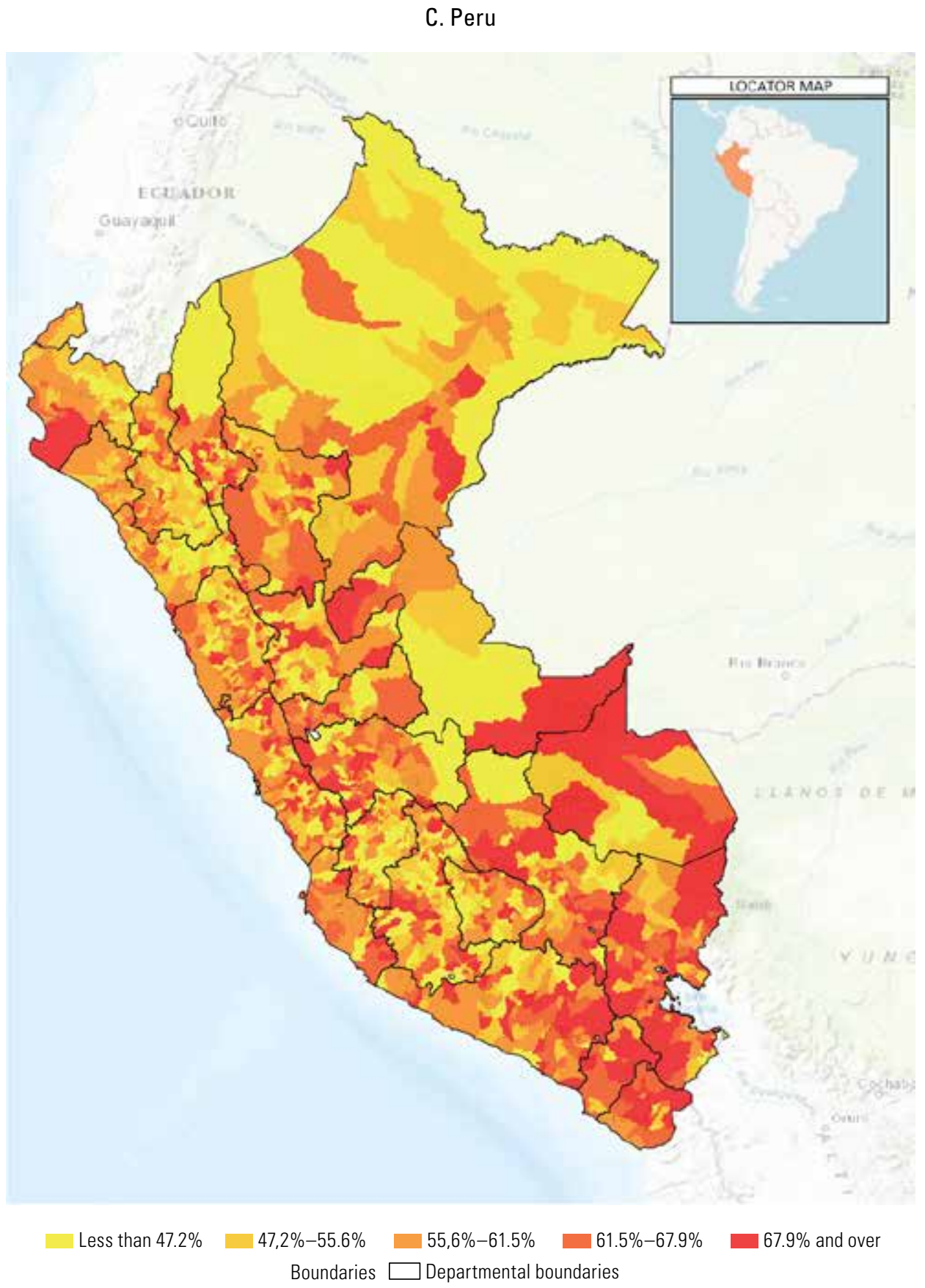

Source: Economic Commission for Latin America and the Caribbean (ECLAC), on the basis of population and housing censuses of the respective countries. Note: The data for Guatemala and Colombia are from the 2018 censuses; the data for Peru are from its 2017 census. 


\section{Living arrangements and coresidence}

The pandemic has heightened pre-existing inequalities in the region and is underscoring the vulnerabilities that threaten some groups' (such as older adults') enjoyment of their rights. The greater risks posed by COVID-19 stand out even more clearly when the types of living arrangements commonly found among such groups are considered. For older persons who reside in multigenerational family households, intergenerational coresidence may be one of the main vectors of contagion (Esteve, Permanyer and Boertien, 2020), while those who live alone may have difficulty obtaining accurate information, food, medications and other essential supplies during quarantines. Older adults who live in long-term facilities such as rest homes and rehabilitation centres are especially vulnerable to infection with COVID-19 and its adverse outcomes.

\section{(a) Intergenerational coresidence as a vector of contagion}

Information on different age groups' living arrangements sheds light on the relative frequency of situations in which different generations share a home or a living space within a dwelling and provides an idea of the level of regular interaction that occurs within a domestic setting. Surveys and censuses are direct means of capturing this information.

The region's diverse age structure, which stems from the advanced, although still evolving, stage of its demographic transition, is conducive to intergenerational contact and the formation of multigenerational households. The higher fertility rates seen in the past (which are now reflected in cohorts of older persons, who have, on average, three or more adult children and a considerable number of grandchildren) are another contributing factor. Yet another is the increase in life expectancy, since the fact that people are living longer may heighten the frequency of intergenerational family living arrangements. In addition, the reproductive inequalities that continue to be observed in the region, whereby fertility rates remain higher among poorer groups, increases the likelihood of intergenerational coresidence in those groups. The still high rate of teenage pregnancy in the region further augments the probabilities of intergenerational coresidence, since young mothers (and in some cases their partners) often stay in the home of their parents (or parents-in-law) and/or grandparents after they have a child (Rodríguez and Cobos, 2014).

There are also a number of other contributing factors, since demographics are only one of the forces that shape family living arrangements. Socioeconomic and cultural factors also tend to reinforce intergenerational coresidence patterns. Because so many older adults' socioeconomic status has deteriorated as they age, multigenerational family living arrangements are often used as a survival strategy or are actually the only available option. In addition, cultural patterns in the region, where family ties are very strong (Ullmann, Maldonado and Nieves, 2014), are also conducive to multigenerational households. Because of all these factors, households in which children, their parents and grandparents live together, often in very cramped quarters, are commonplace.

In most cases, conditions in Latin America and the Caribbean are much the same as they are in other developing regions. In terms of intergenerational living arrangements, however, the region tends to be in an intermediate position between Asia and Africa, on the one hand, and Europe and North America, on the other. As is clearly shown in figure 5, while in Africa and Asia over $60 \%$ of older adults live with one or more of their children, in Europe and North America the figure is below 20\%. The figure for Latin America and the Caribbean is $52 \%$ and so is just slightly lower than the world average (53\%).

There is as yet little solid, first-hand evidence of the role played by family coresidence since, as the epidemic is still under way, researchers need more time to produce representative results. Nonetheless, some European demographers have linked high rates of intergenerational family coresidence in southern Europe with the notably greater scale and severity of COVID-19 cases there and specifically with the higher mortality rates and the collapse of emergency medical systems in those areas (Balbo, Billari and Melegaro, 2020). Since Latin America and the Caribbean share southern Europe's cultural propensity towards strong family ties and are subject, in addition, to economic pressures and insufficient social protection measures for older adults, which promote intergenerational family coresidence or make it a necessity, it is to be expected that multigenerational coresidence rates will be high and especially so in low-income groups. This may therefore be an additional risk factor for contagion with COVID-19. 
Figure 5

World and world regions: persons aged 60 and over, by type of living arrangement, around 1990 and 2010

(Percentages)

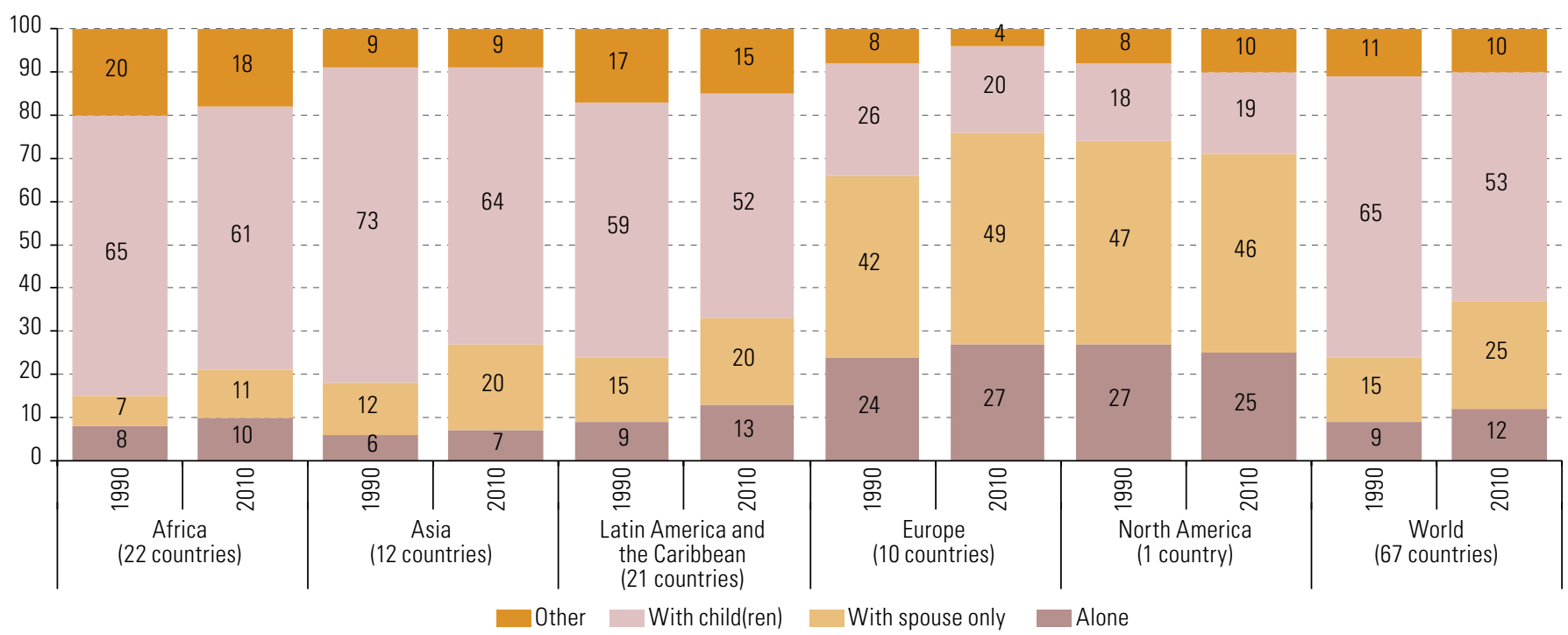

Source: United Nations, Living Arrangements of Older Persons: A Report on an Expanded International Dataset (ST/ESA/SER.A/407), New York, 2017.

By way of example, table 4 sets out recent census (or intercensal survey) data on the living arrangements of persons over the age of 60 and on the size and make-up of the households to which they belong in five countries (Mexico, 2015; Chile and Peru, 2017; Colombia and Guatemala, 2018) of the region. These data are representative of current intergenerational coresidence patterns, since those patterns are structural and therefore slow to change.

Table 4

Latin America and the Caribbean (5 countries): private households that include older adults, by number of persons in the household, persons over the age of 60 and type of living arrangement

(Percentages)

\begin{tabular}{|c|c|c|c|c|c|c|c|c|c|}
\hline \multirow[b]{2}{*}{$\begin{array}{l}\text { Country/ } \\
\text { census year }\end{array}$} & \multicolumn{4}{|c|}{ Panel A - Ageing process at the household level } & \multicolumn{5}{|c|}{ Panel B - Ageing of the population } \\
\hline & $\begin{array}{c}\text { Private } \\
\text { households } \\
\text { with member(s) } \\
\text { aged } 60+\end{array}$ & $1-2$ & $3-4$ & $\begin{array}{l}5 \text { or } \\
\text { more }\end{array}$ & $\begin{array}{l}\text { Persons } \\
\text { aged } 60+\end{array}$ & Live alone & $\begin{array}{l}\text { All older } \\
\text { persons }\end{array}$ & $\begin{array}{l}\text { Other ages } \\
\text { but no } \\
\text { children } \\
\text { aged } 0-14\end{array}$ & $\begin{array}{l}\text { Other ages } \\
\text { including } \\
\text { children } \\
\text { aged 0-14 } \\
\text { and others }\end{array}$ \\
\hline Guatemala, 2018 & 27.0 & 29.8 & 29.1 & 41.1 & 8.1 & 8.0 & 14.5 & 35.7 & 41.9 \\
\hline Peru, 2017 (housing) & 30.4 & 42.4 & 29.8 & 27.8 & 11.9 & 14.2 & 17.5 & 39.2 & 29.1 \\
\hline Chile, 2017 & 35.6 & 50.7 & 32.5 & 16.8 & 16.2 & 14.5 & 24.5 & 41.4 & 19.6 \\
\hline Mexico, 2015 & 28.4 & 42.3 & 31.0 & 26.7 & 10.4 & 11.1 & 21.3 & 39.6 & 28.0 \\
\hline
\end{tabular}

Source: Economic Commission for Latin America and the Caribbean (ECLAC), on the basis of population and housing censuses of the respective countries. 
The prevalence of households that include older adults, who are more vulnerable in the event that they contract the disease, ranges from 27.0\% in Guatemala to 35.6\% in Chile (see panel A of table 4). While these countries' location at the two ends of the spectrum is foreseeable, since Guatemala is the country that is in the incipient stage in the demographic transition while Chile is the most advanced in this respect, the difference between the two is not as great as might be expected, and the overall numbers indicate that around one out of every three households in the region has at least one older adult member and is therefore at greater risk. In all the countries except Guatemala, households that include older adults tend to be quite small, with the largest subgroup being households composed of just one or two people, although, in all of these countries except Chile, a majority of these households are composed of three people or more and thus are more likely to be intergenerational.

The information presented in panel $B$ in table 4 is the more relevant to the subject of interest here, since the unit of reference is the individual, rather than the household, and the residential context corresponds to the different options for intergenerational arrangements. In line with the description given earlier of the demographic ageing process in the region and the world, the data show that the ageing of the population is more advanced in Chile, where it is twice as far along as it is in Guatemala, which has the youngest population of the five countries analysed here. While the figures for the older adult population as a percentage of the total population are certainly not low and are much higher than they were a few decades ago, they are still far from the levels seen in developed countries, where the population aged 60 and over is approaching the 30\% mark (United Nations, 2019a).

Because it appears that children can be a major undetected vector for transmission of the virus, panel $\mathrm{B}$ of table 4 differentiates between multigenerational households with and without children in them. In all the countries except Guatemala, multigenerational households that include children are in the minority, but even so, at least $20 \%$ of older adults live with children, and social distancing measures aimed at children may therefore have an extremely important influence on these older adults' health status.

National figures may translate into very different results in geographic and social terms in each country, however. On a geographic scale, ageing and coresidence levels differ substantially between urban and rural areas, between central and peripheral locations within metropolitan areas, between more or less economically and socially developed regions, etc. As just one example, the results of the Twelfth National Population Census and Seventh National Housing Census of Guatemala indicate that the extent of the demographic ageing process, measured as the percentage of the total population represented by older adults, ranges from $4.6 \%$ in the municipality with the youngest population (Chisec) and $14.7 \%$ for the one with the oldest population (Jerez) (see map 2). A detailed analysis of census data on these geographic patterns should be conducted by each country.

\section{(b) Older adults in single-person households}

Older persons who live alone are a high-risk group under the exceptional circumstances created by the pandemic because they run the risk of being disproportionately affected by physical distancing measures, as they may face hurdles in trying to obtain accurate information, food, medications and other essential supplies during quarantines (Lloyd-Sherlock and others, 2020). In addition, prolonged periods of isolation may have a serious impact on their mental health by leading to an escalation of feelings of loneliness and other undesirable effects (WHO, 2020b). On the other hand, they may be less exposed to contagion, since they do not live with other people who may be more likely to become infected because they have to leave their home to work or to buy essentials.

In recent decades, census results have shown that the number of older adults who live alone is on the rise in most of the countries in the region. A recent comparative study of world regions (United Nations, 2019c) found that: "Most Latin American and Caribbean countries fell in an intermediate position, except for Argentina and Uruguay, which had, respectively as many as 21.2 and 26.7 per cent of their older population living alone." (United Nations, 2019d, p 2). 


\section{Map 2}

Guatemala: population aged 60 and over, by municipality, 2018

(Percentages)

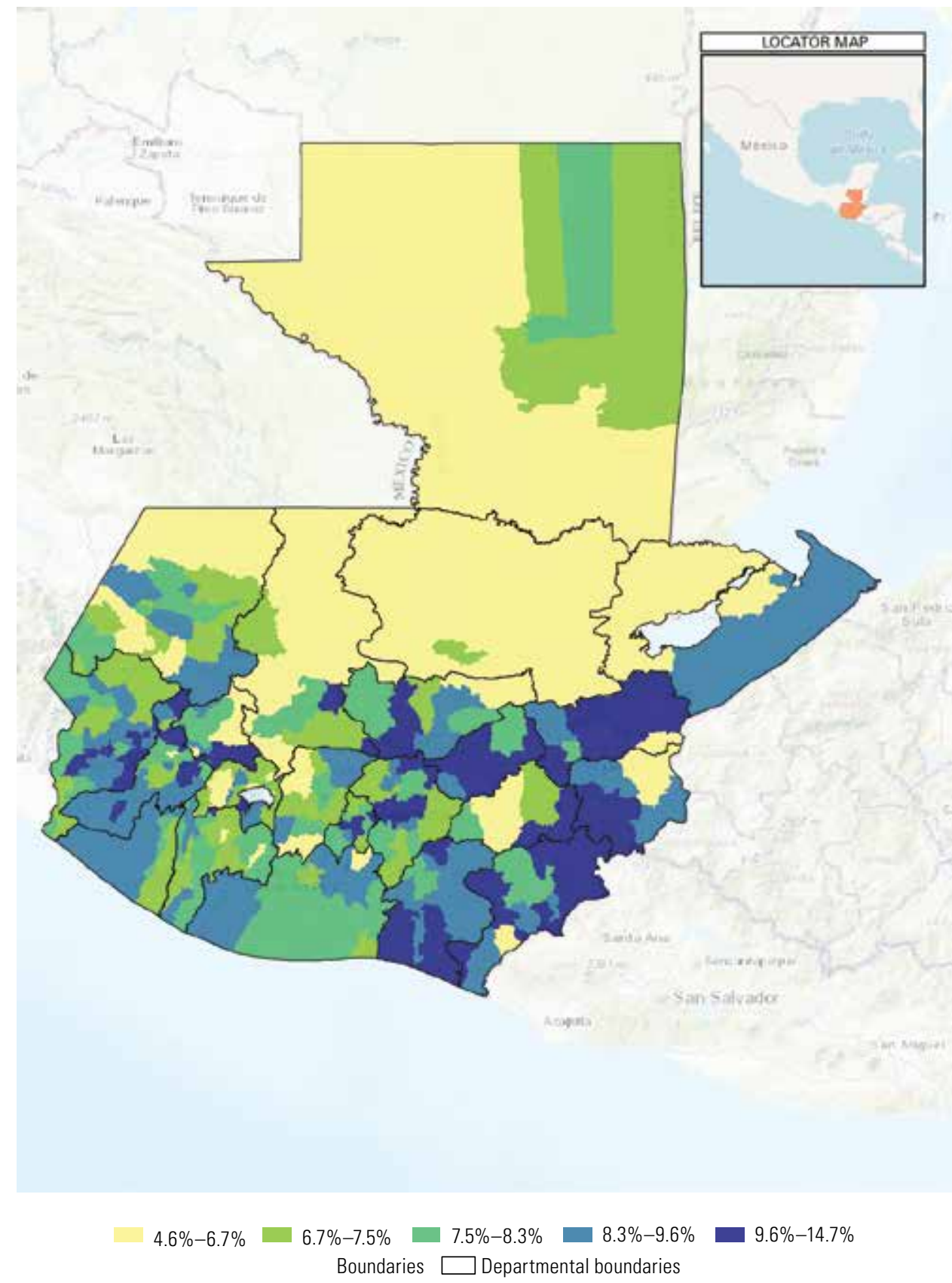

Source: Economic Commission for Latin America and the Caribbean (ECLAC), on the basis of National Institute of Statistics, XII National Population Census and VII National Housing Census, Guatemala City, 2018 [online] https://www.censopoblacion.gt/explorador. 
Recent census data for Colombia (2018), Guatemala (2018) and Peru (2017) and an intercensal survey in Mexico (2015) indicate that the number of people aged 60 or over who live alone ranges from $8 \%$ of the population in Guatemala to $11 \%$ in Mexico and to around $14 \%$ in Chile, Colombia and Peru (see figure 6). It is also interesting to note that between 14.5\% (Guatemala) and 24.5\% (Chile) of persons over 60 years of age live only with other older adults (see figure 6).

Figure 6

Latin America (5 countries): persons aged 60 and over, by living arrangement, according to recent census data (Percentages)

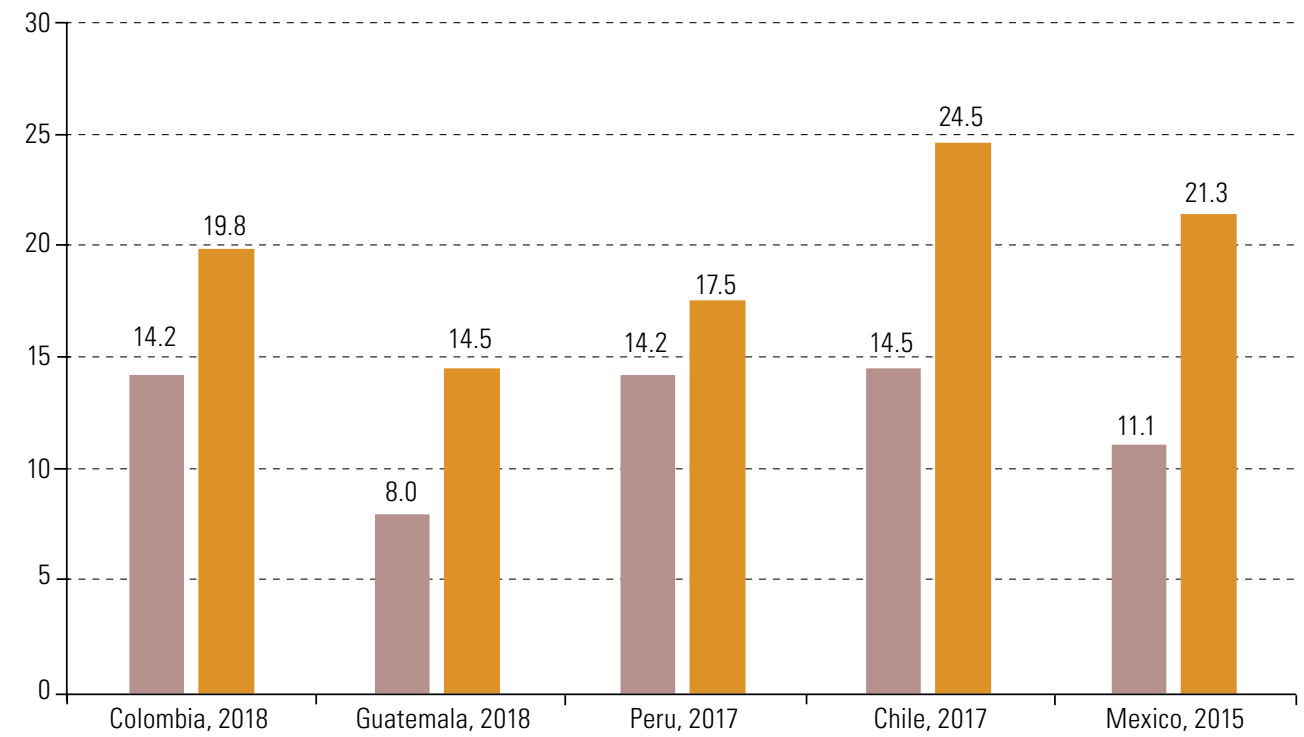

Live alone

Live with other older adults only

Source: Economic Commission for Latin America and the Caribbean (ECLAC), on the basis of census microdata.

Priority action 20 of the Montevideo Consensus on Population and Development refers specifically to people who live alone and those who lack a support network as being among the groups that are most susceptible to discrimination and calls upon the countries to design policies at all levels of government to guarantee the quality of life, development of potential and full participation of older persons, taking account of their need for intellectual, emotional and physical interaction.

Thus, in the presence of the social isolation measures put into effect in response to the pandemic, specific steps need to be taken to support older persons who live alone or with another older adult, as noted by the Inter-American Commission on Human Rights (IACHR, 2020) when it called upon States to consider "the balance that should exist between protection from COVID-19 and older people's particular need to connect with their families, and to provide telephone or internet-based communication channels to prevent their emotional state from deteriorating [...] Likewise, any measures adopted should identify and eliminate obstacles and barriers to older people's access to supplies, public services, care, information, and means of communication during isolation. The IACHR also stressed the need for cooperation between states and private companies that provide essential services and goods to facilitate priority access for older people by implementing special timetables for serving them, as is already being implemented at several supermarket chains and banks in the region."

\section{(c) Older persons who live in institutions}

Older persons who live in long-term care facilities, such as rest homes and rehabilitation centres, are particularly vulnerable to infection with COVID-19 and its adverse effects. Preliminary research at the international level indicates that deaths in these homes accounted for between 19\% and 62\% of all the deaths caused by COVID-19 in Europe and 
Asia (Comas-Herrera and others, 2020, p. 2). In addition, the spread of the virus may interfere with residents' treatment for other chronic diseases and may potentially lead to premature deaths from other causes.

Older adult residents of long-term care facilities are still a small fraction of the older adult population in the region, but their number is growing in those countries that are farther along in the population ageing process. Census data from around 2010 obtained from records of collective housing arrangements show that a mere $0.25 \%$ of this population lives in such facilities (see figure 7), except in Chile and Uruguay, whose populations are older than those of the other countries that were analysed. In absolute values, approximately 166,000 older adults live in such institutions, with no appreciable difference in the number of male versus female members of this group except in Uruguay, where women outnumber men.

\section{Figure 7}

Latin America and the Caribbean: older persons living in long-term facilities, by sex, according to 2010-round censuses (Percentages)

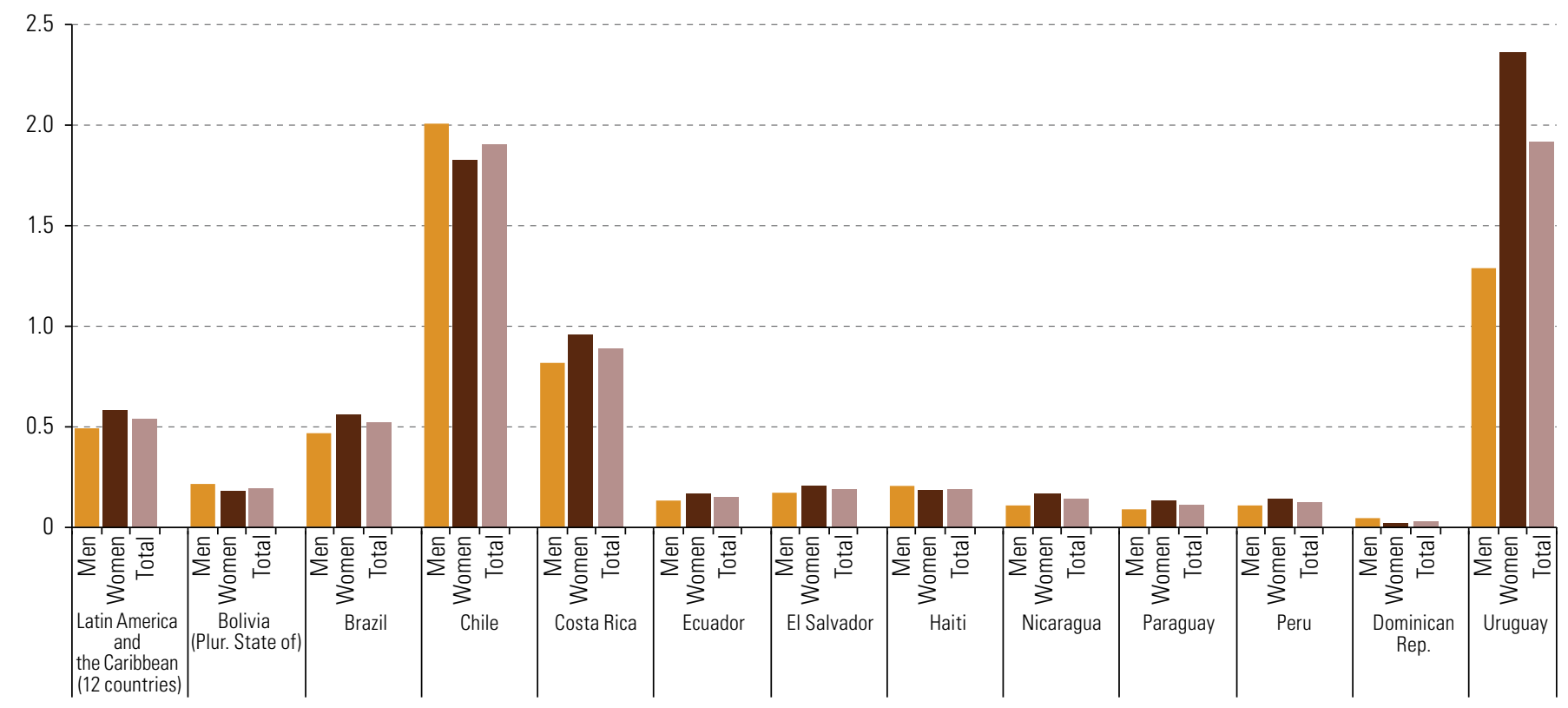

Source: Inter-American Development Bank (IDB), "Indicators: panorama of aging and long-term care", 2020 [online] https://www.iadb.org/en/ panorama/indicators; S. Ruggles and others, "Integrated Public Use Microdata Series: Version 7.0 [dataset]", Minneapolis, University of Minnesota, 2017 [online] https://ipums.org/projects/ipums-usa/d010.v7.0.

The social distancing measures that restrict visits and group activities in these centres may be harmful to the physical and mental health and well-being of older persons, particularly those who are suffering from cognitive decline or dementia and who are heavily dependent on caregivers. A more detailed account of the impact on older persons' mental health and on the measures being recommended by international organizations to mitigate those effects is provided below (see box 2). While most of these measures are primarily intended for older adults living in private homes, some guidelines for older persons residing in institutions are also offered. 
Box 2

Older persons' mental health and COVID-19

The World Health Organization (WHO) has called attention to the need to take timely action to reduce the level of stress and other negative psychological effects of factors directly tied to the outbreak of COVID-19, such as confusion, anger, exhaustion, indifference, anxiety, impaired performance, an unwillingness to engage in activities of daily life and even post-traumatic stress disorder and depression.

The risk of becoming infected and infecting others or of having symptoms of other health problems being mistaken for COVID-19 because the pandemic has prevented people from keeping routine medical appointments can also lead to a deterioration of the physical and/or mental health of older adults. The quarantines that have been instituted in nearly all the countries of the region are another factor, as they are particularly restrictive for older persons and especially for those over the age of 75. Mandatory confinement in the home has impacts on older adults' mental health because it hinders their contact with family members or friends, weakens their social support networks and alters their daily routines. The insecurity caused by the fear of contagion is heightened by loneliness and the feeling of being abandoned, since they cannot receive visits from their families or cannot go out to attend community events such as meetings with their peers in associations of older adults. These feelings are exacerbated by economic and other problems that make it difficult to obtain basic supplies and essential medicines and to go out to do routine errands, all of which can trigger anxiety and distress.

Emotional health is a key factor in enabling older adults to take care of themselves, make appropriate decisions and go on with their lives under protracted adverse conditions.

This is why it is recommended that multidisciplinary teams of mental health professionals provide support for older patients, provide them with clearly stated, accurate information about the situation on a regular basis, offer counselling or psychiatric treatment when needed for those suffering from more serious mental health problems and provide guidelines and advice, tailored to different groups' interests and socioeconomic situation, about what people can do to stay mentally healthy by reducing stress, anxiety and boredom.

Measures considered to be especially useful for older persons who live alone include the following: make sure that they have all the medicines they need in the event of illness; actively maintain their social contacts so that they can ask for help if they need it; be prepared and know beforehand where and how to obtain assistance if necessary (e.g. call a taxi, order food for home delivery or seek medical attention); learn how to do simple physical exercises that can be performed daily at home in order to maintain mobility and reduce boredom; maintain their routines and normal schedules if possible or develop new ones that include regular exercise, housecleaning, daily domestic tasks and other activities such as singing and dancing; stay in regular contact with their loved ones through the channels available to them; encourage their family members and friends to call them regularly and to show them how to make video calls if they do not know how; and learn how to use personal protective equipment such as face masks.

Source: Economic Commission for Latin America and the Caribbean (ECLAC), on the basis of Infobae, "Cómo preservar la salud mental de los adultos mayores durante la cuarentena", Buenos Aires, 26 May 2020 [online] https://www.infobae.com/tendencias/2020/05/26/comopreservar-la-salud-mental-de-los-adultos-mayores-durante-la-cuarentena/; Center for Disease Control and Prevention (CDC), "People with disabilities", 11 September 2020 [online] https://www.cdc.gov/coronavirus/2019-ncov/need-extra-precautions/people-with-disabilities.html.

Another consideration in relation to long-stay facilities is the increased exposure of the medical personnel and health workers who take care of older adults residing in such facilities and the possibility that they may be vectors of contagion (UNFPA, 2020). Steps need to be taken to diminish the physical and psychological stress involved in working during the pandemic, and appropriate protective measures need to be taken to avoid putting everyone, including the residents of these facilities, at risk.

In order to uphold the rights of the older population and to protect caregivers, it is important to identify persons who have been infected without delay, to test them and isolate them while ensuring that they receive proper treatment (WHO, 2020c). Training in the detection of possible cases needs to be provided to caregivers and the full staffing of the relevant facilities has to be ensured in order to contain the spread of the virus (Huenchuan, 2020a). The transfer of older persons to alternative settings as a way of resolving staffing shortages should be avoided whenever possible (CDC, 2020). 


\section{Access for older persons to basic services such as water and sanitation}

Since COVID-19 is a transmissible virus that is spread primarily through respiratory droplets and direct contact, the main ways of avoiding contagion, in addition to staying away from other people, are respiratory hygiene and hand washing. The measures recommended by WHO include the use of face masks but focus mainly on washing hands with soap and water or using an alcohol-based gel (WHO, 2020d). Water also has to be used for cleaning and disinfecting objects and surfaces that a person touches frequently, since direct contact with such objects and surfaces is one of the ways that the virus is transmitted.

As water and sanitation facilities are crucial elements for life, health and hygiene, they play an important role in fighting disease. Older adults' access to these services varies, as they are not a homogeneous group and conditions differ depending on whether they live in urban or rural areas, their state of health, their socioeconomic status and so forth. Although cities have better indicators for access to water and sanitation services, there are enormous inequalities from one area and one social class to another in large cities that are of particular concern for the poorest segments of the population. In slums and other informal settlements, residents may have no regular access to drinking water or sanitation facilities; in most, drinking water is available only sporadically as it is brought in by tanker truck or is obtained from an outdoor standpipe used by many different households. Some of these settlements have witnessed recurring outbreaks of COVID-19 since the triad of overcrowding and a lack of access to drinking water and sanitation facilities makes a fertile breeding ground for contagion and the spread of the virus.

The right to drinking water and sanitation as a fundamental condition for the full enjoyment of life and all human rights is enshrined in a number of international instruments (Huenchuan, 2018). The 2030 Agenda, and particularly Sustainable Development Goal 6, focus on ensuring the availability and sustainable management of water and sanitation for all, including older adults. The report of the Secretary-General on progress towards the Sustainable Development Goals states that: "Immediate action to improve Water, Sanitation and Hygiene for All (WASH) is critical to preventing infection and containing its spread" (United Nations, 2020a, p. 9).

Priority measure 77 (chapter G) of the Montevideo Consensus on Population and Development speaks of the need to "promote the development and well-being of people in all territories, without any form of discrimination and provide full access to basic social services...". The first regional report on the implementation of the Montevideo Consensus noted that ongoing progress has been made in building the infrastructure needed to supply water and sanitation to the population of the region (ECLAC, 2019a). The report also calls attention, however, to the major gaps in access that mirror other inequalities in the region. In rural areas, access to drinking water is limited and, in segregated urban pockets of poverty subject to enormous inequities, the lack of decent housing translates into very limited access to water and sanitation services for the most vulnerable groups in the population. Within these groups, older adults are even more vulnerable because of health and other concerns.

Box 3 provides a more detailed description of the articles of international instruments that underscore the importance of older adults living in a healthful environment and having a sufficient quality of life, it being understood that access to drinking water and sanitation are basic rights that are an essential component of decent living conditions. The importance of these rights stands out even more clearly, as noted earlier, in the midst of this pandemic

The most recent census and intercensal data for five countries indicate that the countries in which the ageing and urbanization processes are the most advanced are the ones where a larger percentage of the population has access to suitable water and sanitation services (see figure 8). The percentage of older persons living in households that lack sufficient access to drinking water ranges from a low of $4 \%$ of the total older population in Chile to a high of 16\% in Guatemala. Rural areas of Colombia and Guatemala are where the largest proportion of older adults lack proper access to the water that is essential in order to contain the spread of COVID-19. 
Box 3

Provisions of international instruments that address the importance for older persons of living in a healthful environment and having an adequate quality of life

\section{Article 25 of the Inter-American Convention on Protecting the Human Rights of Older Persons}

The right to a healthy environment

Older persons have the right to live in a healthy environment with access to basic public services. To that end, States Parties shall adopt appropriate measures to safeguard and promote the exercise of this right, inter alia:

(a) To foster the development of older persons to their full potential in harmony with nature

(b) To ensure access for older persons, on an equal basis with others, to basic public drinking water and sanitation services, among others.

\section{Article 10 of the San José Charter on the Rights of Older Persons in Latin America and the Caribbean}

(Adopted at the Third Regional Intergovernmental Conference on Ageing in Latin America and the Caribbean at San José, Costa Rica, 8-11 May 2012)

10. Seek to improve the living conditions and environment of older persons to strengthen their autonomy and independence by:

a. Making every effort to ensure that older persons enjoy adequate housing and are given high priority in the assignment of housing or land, particularly in situations of crisis, emergency, displacement or development-based evictions;

b. Ensuring that older persons live in a secure, healthy environment and have access to transport facilities and services;

c. Creating and retrofitting age-friendly, safe public spaces, thereby guaranteeing accessibility for older persons by eliminating architectural barriers

Source: Organization of American States (OAS), Inter-American Convention on Protecting the Human Rights of Older Persons, Washington, D.C., 2015; Economic Commission for Latin America and the Caribbean (ECLAC), San José Charter on the Rights of Older Persons in Latin America and the Caribbean (LC/G.2537), Santiago, 2012

Figure 8

Latin America (5 countries): persons aged 60 and over, by access to drinking water services, in urban and rural areas (Percentages)

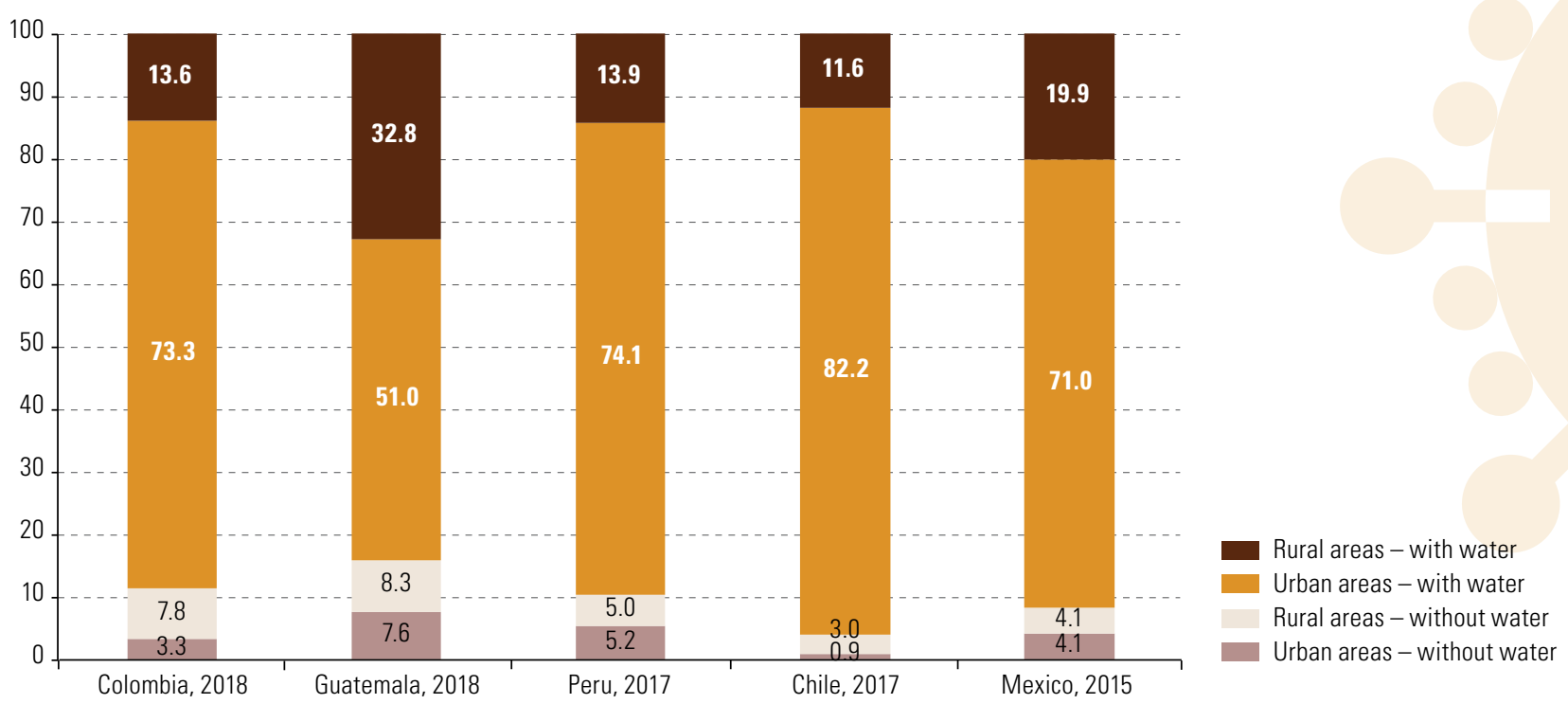

Source: Economic Commission for Latin America and the Caribbean (ECLAC), on the basis of census microdata.

Note: The total does not include the categories "not applicable" (which, in some of the censuses, covers older persons living in collective dwellings and/or homeless older persons), "unspecified", "not reporting", "does not prepare food", and/or "no response", or those of rental housing, vacation homes, absent residents or a combination of a number of these subcategories. 
The situation with respect to household access to sanitation facilities is substantially worse for older persons in rural areas (see figure 9). The most recent census data indicate that nearly $30 \%$ of older persons living in the rural areas of Guatemala and almost $13 \%$ of those in Peru do not have sufficient access to sanitation facilities; the corresponding figures are lower for both Colombia and Mexico. In most of these countries, the situation varies quite markedly across different subnational areas, with urban areas being highly segregated and rural areas being very poor. It is therefore important to obtain detailed information on where people in need of assistance are and how many of them there are so that steps can be taken to ensure that the necessary infrastructure to provide access to drinking water and sanitation services is in place. This is a human right, and upholding it is all the more urgent during a health crisis where the ability to maintain proper hygiene can spell the difference between life and death.

Figure 9

Latin America (4 countries): persons aged 60 and over, by access to sanitation services in urban and rural areas (Percentages)

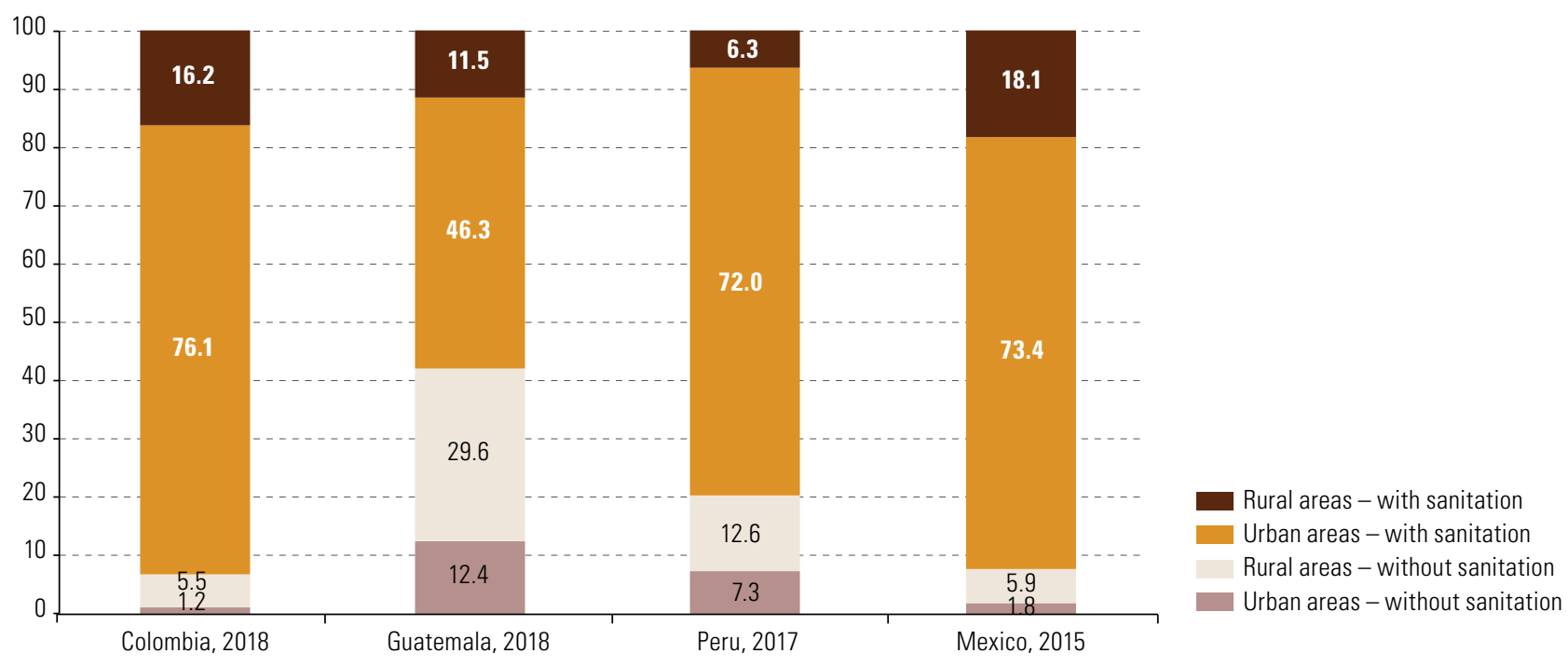

Source: Economic Commission for Latin America and the Caribbean (ECLAC), on the basis of census microdata.

Note: The total does not include the categories "not applicable" (which, in some of the censuses, covers older persons living in collective dwellings and/or homeless older persons), "unspecified" or a combination of a number of these subcategories.

The indicators for sufficient access to water and sanitation that are used in censuses and surveys usually provide information only on the type of access that there is in the dwelling. They do not measure water quality or how many times per day these services are available. Nor do they show whether sewage is properly treated before being released into the environment; when it is not, it often contaminates water sources or systems used by many other people. Strict policy guidelines need to be applied to water supplies and sanitation services, which are an essential public health issue and a fundamental human right that is all the more important during a pandemic.

\section{The need to expand and upgrade social protection systems, particularly for older persons}

A rapid response to the devastating social and economic impacts of COVID-19 is needed as a matter of urgency in order to protect the human rights and dignity of older adults. The purpose of social protection systems - with this term being understood as encompassing the entire set of actions taken by public and private agencies to lighten the load for households and individuals of certain kinds of risks and needs that arise throughout a person's life and to build their resilience in the face of unexpected or unavoidable events (accidents, illness, 
job loss, natural disasters, etc.) - is to integrate a range of different types of measures aimed at building more just and inclusive societies and ensuring a certain minimum living standard (Arenas de Mesa, 2019).

The importance of improving and expanding access to social protection systems that address older persons' needs effectively has been recognized in various international instruments, such as article 17 of the Inter-American Convention on Protecting the Human Rights of Older Persons (OAS, 2015), the San José Charter on the Rights of Older Persons in Latin America and the Caribbean, ${ }^{5}$ the Montevideo Consensus on Population and Development (priority actions 26 and 31), ${ }^{6}$ target 1.3 of the Sustainable Development Goals ${ }^{7}$ and the Asunción Declaration. ${ }^{8}$ The right to social protection (health, income, pensions) was being violated before the pandemic hit the region - the region with the greatest degree of inequality in the world - and, if the structural factors that have resulted in older, vulnerable persons (the poorest, older women, those who are most dependent) being left so far behind are not addressed, particularly during this health crisis, there is the risk that these groups' lack of protection will become even more severe.

Given the demographic shifts that are occurring in the region as the population ages, life expectancy increases, family size diminishes and the urbanization process advances, the Montevideo Consensus focuses on three major areas in which social protection systems need to be adapted to meet the needs of older persons: pensions, basic health care and social services to support personal independence (ECLAC, 2019a). Now, as the region grapples with the COVID-19 pandemic, the public health measures that have been taken and the response mounted in terms of diagnostics and treatment in the region's hospitals should be continued, and consideration must also be given to expanding primary health-care services throughout the entire region as part of an overall primary health-care strategy (ECLAC/PAHO, 2020). Guaranteeing income security is also essential.

Before the pandemic, health-care services were mainly looking for ways to provide greater access while dealing with the growing cost of treating the chronic and degenerative diseases of an ageing population. Now, with the advent of the health crisis, those costs have soared as a new communicable disease - one that is much more deadly than other viral diseases, is extremely expensive to treat and whose long-term effects are unknown - takes its greatest toll on older persons with pre-existing conditions

As mentioned earlier, priority action 26 of the Montevideo Consensus reflects the countries' resolve to bring policy measures into line with the new epidemiological profile that is taking shape as the countries' populations age. While this is crucial, there needs to be an awareness of the fact that inequalities grow sharper over people's lifetimes, and older persons are therefore not a homogeneous group; instead, older persons are living under differing economic and social conditions, and their access to health is therefore differentiated as well. Older adults' access to health, which is everyone's right, is marked by inequality, and genuine universal access is therefore not a reality for older persons in the region. The COVID-19 pandemic has rekindled the discussion about how to adapt the health system in order to provide access and broad coverage not only for people suffering from chronic conditions but also for those who are infected with a virus that can lead to their premature death.

One consideration in the debate about the idea of providing a guaranteed income is the pandemic's potential to significantly lower older persons' incomes and living standards. ECLAC has predicted that, as a consequence of COVID-19, GDP will fall by at least $9 \%$ while increases will be seen in unemployment (3.4 percentage points), poverty (7.1 percentage points, or some 28.7 million more people) and extreme poverty (4.5 percentage points,

5 "Agree to improve social protection systems so that they effectively meet the needs of older people" (ECLAC, 2012, p. 9)

6 "Bring health policies into line with the challenges of the varied and changing epidemiological profile arising from ageing and the epidemiological transition..." and priority measure 31: ". Include care in social protection systems..." (ECLAC, 2013, pp. 19-20).

7 The 2030 Agenda: Target 1.3 of the Sustainable Development Goals recognizes that the overall and principal responsibility of the State is to apply the principle of the universality of social protection. (United Nations, 2015)

8 Asunción Declaration, paragraph 9: "Urge the Governments to take specific measures and intensify existing measures to combat age-based and multiple discrimination, abandonment, mistreatment and violence towards older persons, affording particular attention to those in situations of greatest risk and social vulnerability, and to provide comprehensive health services, care, social protection and access to food, housing, employment, social occupation and justice, among others." (ECLAC, 2017, p. 2) 
or 15.9 million more people) (ECLAC, 2020c). The economic recession and other more wide-ranging repercussions of the pandemic may leave many older persons, particularly older women and older adults with disabilities, worse off, with few job opportunities and with pensions and social protection benefits that are even more inadequate than they were before.

Recent ECLAC studies confirm that pension systems in the region, which were already paying out very small benefits and were already beset by financial problems, will also be hurt by the pandemic as their membership and/or contributions shrink, especially in countries that will see the sharpest increases in unemployment and informal employment. This will have implications for the systems' revenues from contributions and for the density of contributions at the time of retirement, which could ultimately reduce payouts and deepen existing gender inequalities (ECLAC, 2020b).

The first regional report on the implementation of the Montevideo Consensus (ECLAC, 2019a) notes that the issue of income security for older adults is still pending on the agendas of all the countries. Because there is so much economic inequality in the region and such a high percentage of jobs do not provide social security coverage, there is an enormous gap that needs to be closed by the establishment or improvement of non-contributory pension systems. These systems are increasingly difficult to maintain, however, in the midst of economic and fiscal crises and with a workforce that is shrinking relative to the growing older population.

As of 2015, when effective pension coverage was measured by Sustainable Development Goal indicator 1.3.1 (the proportion of the population covered by social protection floors/systems), $30 \%$ of the population over 65 years of age did not have the necessary minimum level of coverage. This gap was considerably smaller than it had been before, however, primarily thanks to the effect of non-contributory pensions (ECLAC, 2018 and 2019b).

The most recent data available for the countries of the region (see figure 10) show that, despite an increase in coverage, the inequalities and benefit shortfalls of their pension systems remain very serious. In fact, for the economically active population over the age of 15 , only $47.5 \%$ of those in the lower-middle income bracket belonged or were paying into a pension system in 2017; that figure rose to $60.1 \%$ for intermediate middle-income brackets and to $69.8 \%$ for those in upper-middle income brackets (ECLAC, 2019a).

Figure 10

Latin America (18 countries): payments into or membership in a pension system among economically active persons over the age of 15, by per capita income stratum, around 2017 (Percentages)

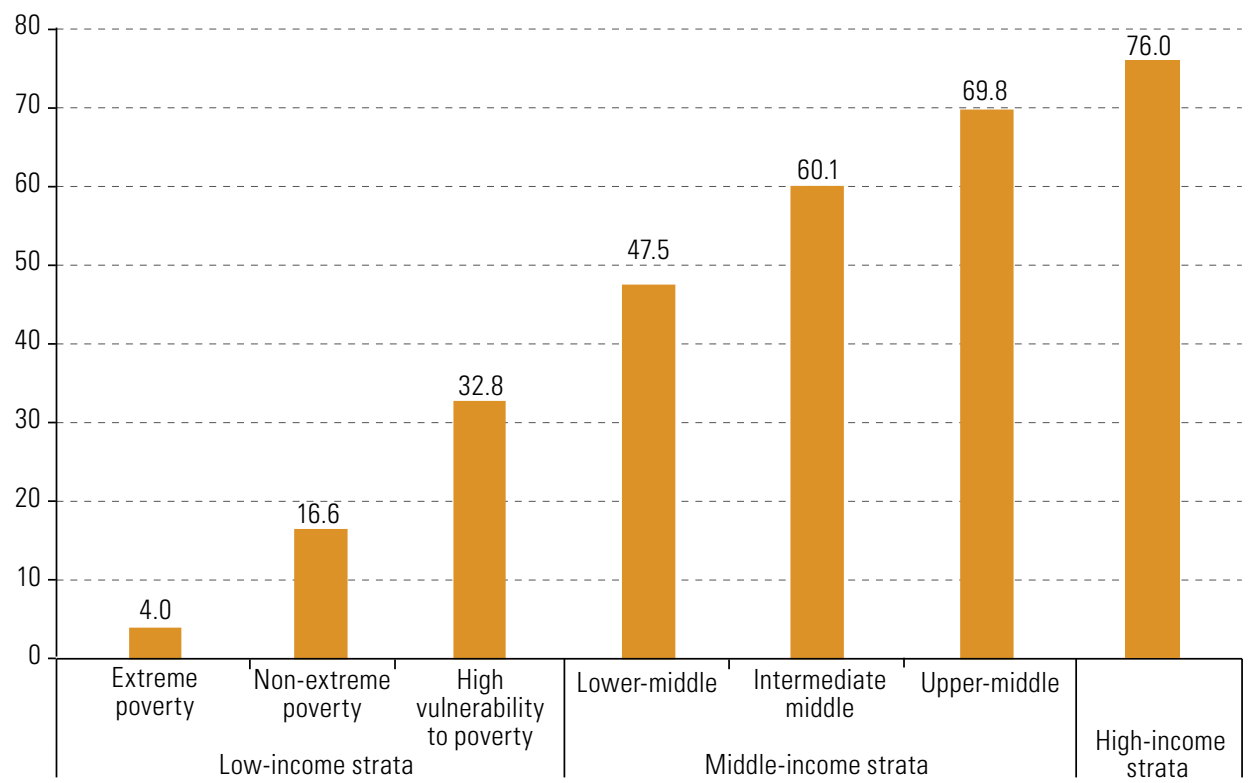

Source: Economic Commission for Latin America and the Caribbean (ECLAC), Social Panorama of Latin America, 2019 (LC/PUB.2019/22-P/Rev.1), Santiago, 2019. 
According to the most recent figures available, pensions are less than US\$ 295 for $76.8 \%$ of adults over the age of 65 who receive pensions under a contributory system (ECLAC, 2019a). During economic crises such as the present one, the need for cash resources is often greater, of course, and in many cases an older adult's income is the main or only source of income for a household under such circumstances. Additional support measures that have been introduced in some cases include: (i) special benefits for retirees with the smallest pensions and, in some cases, small supplementary benefits for those with larger pensions; (ii) advance pension payments for a set number of months; (iii) authorization of withdrawals from individually funded accounts (ECLAC, 2020b)

Long-term care is another issue that has taken on even greater importance during this health crisis. The mortality rates for COVID-19 have been especially high among people over the age of 80, many of whom are living in institutions or being cared for in their homes by people who are not necessarily professional caregivers or who have the proper training. While the situation in Latin America and the Caribbean has improved, mainly in terms of legislation, in recent years, much of the responsibility for providing care and other unpaid domestic tasks is still borne by family members and especially women family members (ECLAC, 2019b).

As has been noted by ECLAC, the pandemic has provided more evidence than ever before of how important caregiving is in sustaining life, how nearly invisible this sector is in the region's economies and how overburdened women caregivers are. Before this crisis, women devoted three times as many hours as men did to these kinds of tasks. Now, in the midst of this health emergency, when the countries' health-care systems are working at top capacity, many aspects of the care of older persons has been transferred to the household and, in the absence of co-responsibility policies, the amount of home-based caregiving that is needed has no doubt increased, and much of this added burden is being shouldered by women (ECLAC, 2020a).

In the context of the current economic and unemployment crisis, the International Labour Organization (ILO) has said: "Care services can generate millions of jobs to address the shortage of skilled care workers, estimated at 13.6 million globally. Efforts are needed to improve working conditions for many health and care workers, including labour rights and adequate compensation, to transform unpaid work into decent jobs and contribute to full employment and inclusive growth" (ILO, 2017). Training and appropriate legislation are essential in order to protect not only workers but also older adults, especially since the latter are often victims of mistreatment at the hands of caregivers, and this problem may be aggravated under lockdown conditions.

The Inter-American Convention on Protecting the Human Rights of Older Persons facilitates the standardization of legislation for the expansion of the health and care services provided by social protection and social security systems in the region. The priority actions set out in the Montevideo Consensus should be implemented in the light of this instrument as the region strives to address the problems that are now being exacerbated by the COVID-19 pandemic.

\section{B. National and local measures targeting older adults}

Ever since the outbreak of COVID-19, even before it became a pandemic, WHO was publishing daily bulletins and other surveillance reports in an effort to prevent the further spread of infection and, once that had become inevitable, to stave off the collapse of the countries' health-care systems under the watchword "test, isolate, treat and trace". In addition to acting upon the health recommendations issued by WHO, the countries are putting in place other social and economic measures to aid the most vulnerable groups in the population and people who have lost their sources of income during the quarantines.

The initiatives adopted by five countries in the region (Chile, Colombia, Guatemala, Mexico and Peru) that specifically target the older adult population involve a number of different approaches. Some launched plans for this segment of the population that call for various types of measures, as in the case of Peru (Legislative Decree DL1474, 2020), aimed at strengthening appropriate comprehensive and protective measures (Congress of Peru, 2020, p. 3) required during the COVID-19 health crisis to aid older adults, and, in Chile (the Older Adult Protection Plan), in an effort to help to provide support for persons over the age of 80, who were instructed to remain in their homes during the COVID-19 emergency (SENAMA, 2020). 
Other countries have issued more specific standards, guidelines and/or protocols setting out instructions regarding health-related measures and restrictions on forms of behaviour in long-term residential facilities. Some instituted mandatory social distancing precautions or lockdowns in long-stay facilities (Colombia), while others introduced specific plans concerning the home confinement of the older population (Chile, Colombia) and still others distributed guidance on the prevention of the spread of COVID-19 in residential facilities for older adults (Mexico).

On the economic front, the great majority of countries (including Chile, Guatemala and Peru) have distributed emergency funds or food to the most vulnerable sectors of the population, which have indirectly benefited older persons. Others (including Colombia) have distributed subsidies directly to older adults.

One major health-related measure taken in some countries that has indirectly helped to uphold the rights of older adults has been the expansion of hospital infrastructure in order to avert the collapse of the health system. This measure has figured prominently in government actions in line with WHO recommendations. None of the above-mentioned countries appears to have issued specific instructions for the protection of those rights in the case of older persons, however, or for preventing discrimination against them in access to health services at a time when those resources are under such severe strain as they are at present.

Various measures have thus been implemented at different points in time that involve varying degrees of interaction between the government sectors concerned. Some countries have taken precisely targeted clear-cut policy action aimed at the older adult population, while others have included this group in the overall segment of the population that is defined as vulnerable. WHO instructions and recommendations concerning precautionary and hygiene measures were distributed to the countries' populations, but civil society and governments have sometimes been slow to react to the seriousness of the pandemic, and this hampered the proper implementation of those instructions and recommendations. Box 4 provides an overview of some of the actions and measures adopted by countries of Latin America and the Caribbean.

Box 4

Measures taken in countries of the region to protect older persons from COVID-19

- Chile: The Older Adult Protection Plan provides for a series of measures to shield persons over 80 years of age, who are required to stay in their homes as a precautionary measure. The "Food for Chile" Programme calls for a number of measures such as the delivery of food boxes to the groups hit the hardest by COVID-19. The public and private hospital systems have been working together as a network to treat COVID-19 patients; this has benefitted the whole of the population but especially older adults, since they are the group that has been affected the most by the virus. Special residential arrangements have been put in place for persons with mild symptoms of the coronavirus who need to be isolated, with basic care and meal services being provided primarily to people who live alone or with members of high-risk groups. Economic schemes such as emergency household income subsidies have been set up, and Congress has approved withdrawals of up to $10 \%$ of the funds held in people's pension accounts.

- Colombia: Services for persons over 70 have been classified as essential services. Additional payments have been made to beneficiaries of the Colombian Older Adult Programme, and measures have been introduced to protect the rights of pensioners, persons receiving the Social Service's regular supplementary payments (known by the Spanish-language acronym of BEPS) and beneficiaries of the Pension Contribution Subsidy Programme. Preventive isolation measures have been introduced for older adults in long-stay facilities together with partial closures of life activity centres and day centres, from which older adults are allowed to leave only under exceptional circumstances. The Ministry of Health has issued specific guidelines for the prevention, containment and mitigation of COVID-19 in homes for older persons, life centres, day centres and long-stay shelters. In order to protect and support older adults displaced by the closure of life centres and activity centres, the National Unit for Disaster Risk Management has issued a directive to local governments that provides for meal deliveries for vulnerable older adults 
- Costa Rica: The government has placed special emphasis on the needs of older persons. The National Council for Older Persons (CONAPAM) is carrying out a campaign for the prevention of violence against older persons and the promotion of respect for their human rights, including the right to care and treatment. A plan is being implemented for the prevention of cases of COVID-19 in long-stay homes and for the treatment of those who do become infected, and approval has been given for the expansion of the home care network so that it can serve over 14,800 older beneficiaries.

- Cuba: The Ministry of Health has strict preventive measures in place to protect the lives of older persons. Both for older adults and for the rest of the population, strategies are being pursued that revolve around proactive research, case classification, contact tracing, special treatment for vulnerable groups and the monitoring of discharged coronavirus patients. Each residential home for older adults is registered with a specific hospital for the treatment of residents. Every centre also has a small clinic staffed with a family physician and a nurse and social workers trained to keep track of respiratory problems and to follow a treatment protocol at the first sign of symptoms. Rest homes also have medical and nursing personnel on staff. These facilities are monitored regularly, cases of respiratory infections are reported and there are isolation rooms on the premises. In addition, persons who attend day centres are provided with meals at home in order to avoid the risk of contagion.

- El Salvador: The Response and Economic Relief Plan provides for a number of different economic and social measures for softening the blow dealt by the spread of COVID-19. The measures targeting older persons include an order for all public and private companies to send home any worker over the age of 60, without exception. Those employees will not lose any pay, and employers are to facilitate teleworking if possible.

- Guatemala: The Ministry of Health and Social Assistance advises the public of the directives that are being issued, one of which directs employers to consider allowing workers over 70 years of age and those with serious medical conditions to work remotely. In addition, workplace recreation centres have been closed, and visits to shelters or homes for older adults are restricted. A programme has also been established for the distribution of meals and the implementation of various measures to prevent the spread of COVID-19. Economic measures include economic relief legislation designed to aid vulnerable households to weather the effects of the pandemic. In addition, 200,000 food boxes (the "We Will Get Through This Together" Programme) donated by private companies have been distributed by the executive branch and the Ministry of National Defence.

- Mexico: Pension payments from the Older Adult Welfare Programme for a total of US\$212.55 per person (equivalent to the payments for March-April and May-June) were provided in advance of their normal dates. The government has set up a website for the public that provides essential information about COVID-19 (Government of Mexico, 2020b).

- Panama: Medications are being distributed by the Social Security Fund, mainly for persons over the age of 65 and those suffering from chronic conditions, and authorized personnel are making home visits to older persons. Shelters and residential homes are being georeferenced to facilitate the identification of older adults living in long-term nursing homes

- Dominican Republic: The government has assigned top priority to older persons: people over the age of 59 can be tested for COVID-19 free of charge, an additional cash transfer in the amount of US\$ 120 is being given to households in which an older adult resides, meals are being delivered to people's homes and protective gear is being distributed to older persons who attend day centres. Steps are also being taken to promote co-responsibility for the care of older persons by recruiting young volunteers to deliver home meals to older persons.

- Peru: Preventive and precautionary measures are included in a wide-ranging action plan for combatting COVID-19 under which a high-level multisectoral committee has been set up to oversee the work of coordinating efforts to prevent and control the spread of COVID-19 and to help protect people from infection. Legislative Decree No. 1474 is designed to aid older adults and to ensure that they can receive treatment and are protected during this health emergency. It provides for a series of measures and specifies the duties of the State and of a number of other sectors in protecting this group and upholding the rights of older persons living in homes and long-stay residential facilities. As part of the action plan for the implementation of a support network for high-risk older adults and persons with severe disabilities, this sector of the population has been identified and georeferenced so that its members can be traced and service packages can be delivered to them during the pandemic. An economic emergency decree has been issued under which cash transfers are being made to members of at-risk groups. In addition, a support network provides health and hygiene information, assists with the identification of signs of infection and helps to arrange for flu shots.

Source: Economic Commission for Latin America and the Caribbean (ECLAC), COVID-19 Observatory in Latin America and the Caribbean [online] https://www.cepal.org/en/topics/covid-19; S. Huenchuan, "El derecho a la vida y la salud de las personas mayores en el marco de la pandemia por COVID-19" (LC/MEX/TS.2020/9), Mexico City, Economic Commission for Latin America and the Caribbean (ECLAC), 2020; Government of México, "Adultos mayores", 2020 [online] https://coronavirus.gob.mx/adultos-mayores/. 
While these preventive and precautionary measures have been based on WHO recommendations, they have also had to be adapted to local conditions. The coordination of the measures introduced by the countries' governments at all levels and by individual members of civil society and civil society organizations, including health specialists, have determined the course taken by the pandemic in the various countries.

\section{Policy recommendations}

The Latin American and Caribbean countries have responded in differing ways to the outbreak and spread of COVID-19, have registered differing numbers of cases and deaths, and are still beset by a great deal of uncertainty as to the scale of the pandemic and its economic, social and psychological implications. This pandemic has posed unprecedented challenges for humankind and poses a tremendous threat to the health, lives, rights and well-being of older persons. The recovery from the COVID-19 pandemic will be an opportunity to build a more inclusive, equitable and friendly society that promotes health in old age and the human rights and dignity of older persons. A number of specific recommendations can be made on the basis of the situation outlined in this report:

1. The international instruments that have emerged from in-depth deliberations and that are now being implemented are reference tools for the prioritization of measures for softening the impact of the pandemic as much as possible and for upholding the rights of older adults and the population at large. These instruments include the Madrid International Plan of Action on Ageing, the San José Charter on the Rights of Older Persons in Latin America and the Caribbean, the Inter-American Convention on Protecting the Human Rights of Older Persons, the Montevideo Consensus on Population and Development, the 2030 Agenda for Sustainable Development and the Asunción Declaration.

2. The trends associated with the ageing of the population take on greater importance during a pandemic in which older persons are at a significantly higher risk of becoming gravely ill and dying from COVID-19. The countries therefore need to design explicit policies for the protection of older persons that will shield them from contagion and that, in the event that they do become infected, will ensure that they will have access to suitable treatment, without discrimination of any kind. The countries also need to take action to provide treatment for the disease and its consequences and to set in motion plans for organizing vaccination drives for older persons and assigning priority to the most vulnerable groups.

3. Policies need to be informed by a recognition of the fact that "older persons, by virtue of their age and vulnerability, continue to be subjected to discrimination, abuse and ill-treatment, which ultimately impairs the enjoyment and exercise of their rights" (ECLAC, 2013, p. 18). Long-stay facilities therefore need to be provided with public policy support for the training and certification of staff and with the necessary funding to ensure that residents receive the best possible care at all times but especially during health crises such as the present one.

4. A direct policy implication of the information compiled on intergenerational coresidence is that the closure of schools and lockdowns are the most effective means of reducing the risk of contagion, although they are essentially unsustainable over long periods of time and clearly produce collateral damage. Some of the other options, such as having older persons self-isolate within the home, have proven to be more difficult to implement successfully. There are also complementary approaches, however, such as the use of special convalescent facilities to permit the isolation of COVID patients. The adoption of strict rules of hygiene in the home (handwashing, the use of face coverings or masks, social distancing, the regular disinfection of counters and other such surfaces, etc.) is also helpful, but very little evidence is available on how closely such rules are followed within the home.

5. Social support measures are needed in order to ensure that people who live alone or who are socially isolated are checked in on during the pandemic and provided with information about how to seek help if they need supplies and medicines, as well as emotional support. Administrative records therefore need to be kept on older people who live alone that list emergency contacts and other particulars. 
6. At all times (not just during a pandemic), older persons need access to water and sanitation facilities in order to protect themselves from communicable diseases. Both in rural areas and in segregated and poor areas within the cities that lack sufficient water and sanitation services, targeted action needs to be taken to ensure a continuous and appropriate supply of these services in the short, medium and long terms.

7. As the population ages and its epidemiological profile is altered by the mounting prevalence of chronic and degenerative illnesses, the health-care system will need to be organized in ways that will enable it to provide the best possible primary health services and be better prepared for times such as these so that it can offer the necessary treatment to the older population as a matter of course.

8. The region's long-standing shortcomings in the area of social protection will not be surmounted overnight. During a health crisis that is exacerbated by a deep economic recession, steps have to be taken to ensure that older adults receive their pensions, and this is especially important for the most vulnerable among them: those receiving pensions under the non-contributory system and those who have no pension coverage at all. Urgent action needs to be taken to identify and locate vulnerable persons, and the establishment of distribution channels for getting assistance to them needs to be a top political priority.

9. Because of the weakness of the region's social protection systems, the relegation of many women to unpaid work, and women's greater caregiving burden and their longer life expectancy, gender inequities must be taken into consideration in all policies and measures. One of the most important challenges to be overcome by the region is the social reorganization of caregiving systems so that the State, the market and families share this responsibility equally.

Lastly, but no less importantly, much more information is needed on all the issues dealt with in this report in order to permit their more thorough analysis. The crisis has underscored the glaring need for robust data collection and dissemination systems and for the disaggregation of data at the subnational level by age, sex and cause of death. Appropriate policies and sufficient funding are therefore needed to permit the design and improvement of indicators for use in monitoring the epidemiological progression of the pandemic and for tracking the socioeconomic and demographic patterns needed to identify the most vulnerable groups and risk factors. 


\section{Bibliography}

Arenas de Mesa, A. (2019), Los sistemas de pensiones en la encrucijada: desafíos para la sostenibilidad en América Latina, ECLAC Books, No. 159 (LC/PUB.2019/19-P), Santiago, Economic Commission for Latin America and the Caribbean (ECLAC).

Balbo, N., F. Billari and A. Melegaro (2020), "The strength of family ties and COVID-19", Contexts, Washington, D.C., American Sociological Association, 6 April [online] https://contexts.org/blog/structural-shocks-and-extreme-exposures/\#balbo.

Brasil, Government of (2020), "Open DataSUS" [online database] https://opendatasus. saude.gov.br/.

CDC (Center for Disease Control and Prevention) (2020), "People with disabilities", 11 September [online] https://www.cdc.gov/coronavirus/2019-ncov/need-extraprecautions/people-with-disabilities.html.

Chile, Government of (2020), "Cifras oficiales COVID-19" [online database] https://www. gob.cl/coronavirus/cifrasoficiales.

Chinese Center for Disease Control and Prevention (2020), "Vital surveillances: the epidemiological characteristics of an outbreak of 2019 novel coronavirus diseases (COVID-19) - China 2020", China CDC Weekly, vol. 2, No. 8, Beijing.

Cisternas, M. and V. Pineda (2020), "Declaración conjunta: gobiernos locales y personas con discapacidad en relación al COVID-19", New York, United Nations, 5 May [online] https://www.un.org/development/desa/disabilities/wp-content/uploads/ sites/15/2020/05/Decl-Gobiernos-locales-y-pcd-Covid-19-5mayo-F.pdf.

Comas-Herrera, A. and others (2020), "Mortality associated with COVID-19 outbreaks in care homes: early international evidence", London, International Long-Term Care Policy Network, 3 May [online] https://tccovid.org/wp-content/uploads/2020/05/ Mortality-associated-with-COVID-3-May-final-7.pdf.

Congress of the Republic of Peru (2020), "Decreto legislativo No 1474", El Peruano, Lima, 2 May.

Dowd, J. and others (2020), "Demographic science aids in understanding the spread and fatality rates of COVID-19", Proceedings of the National Academy of Sciences (PNAS), vol. 117, No. 18, Washington, D.C., National Academy of Sciences (NAS).

ECLAC (Economic Commission for Latin America and the Caribbean) (2020a), "The COVID-19 pandemic is exacerbating the care crisis in Latin America and the Caribbean", COVID-19 Reports, Santiago, April.

(2020b), "The social challenge in times of COVID-19", COVID-19 Special Report, No. 3, Santiago, May.

(2020c), "Measuring the impact of COVID-19 with a view to reactivation", COVID-19 Special Report, No. 2, Santiago, April.

(2019a), First regional report on the implementation of the Montevideo Consensus on Population and Development (LC/CRPD.3/6), Santiago.

(2019b), Social Panorama of Latin America, 2019 (LC/PUB.2019/22-P/Rev.1), Santiago. (2018), Social Panorama of Latin America, 2017 (LC/PUB.2018/1-P), Santiago.

(2017), Asunción Declaration: Building inclusive societies: ageing with dignity and rights, Santiago.

(2013), Montevideo Consensus on Population and Development (LC/L.3697), Santiago.

(2012), San José Charter on the Rights of Older Persons in Latin America and the Caribbean (LC/G.2537), Santiago.

ECLAC/PAHO (Economic Commission for Latin America and the Caribbean/Pan-American Health Organization) (2020), "Health and the economy: a convergence needed to address COVID-19 and retake the path of sustainable development in Latin America and the Caribbean", COVID-19 Reports, Santiago.

Esteve, A., I. Permanyer and D. Boertien (2020), "La vulnerabilidad de las provincias españolas a la COVID-19 según su estructura por edad y de co-residencia: implicaciones para el (des)confinamiento", Perspectives démografiques, No. 19, Barcelona, Centre for Demographic Studies

González, D. and M. Stang (2014), "Las personas con discapacidad en América Latina a 20 años de los consensos de El Cairo: la necesidad de información para políticas y programas", Population Notes, No. 99 (LC/G.2628-P), Santiago, Economic Commission for Latin America and the Caribbean (ECLAC). 
Guilmoto, C. (2020), "COVID-19 death rates by age and sex and the resulting mortality vulnerability of countries and regions in the world", May [online] https://www. medrxiv.org/content/10.1101/2020.05.17.20097410v1.

Huenchuan, S. (2020a), COVID-19: recomendaciones generales para la atención a personas mayores desde una perspectiva de derechos humanos (LC/MEX/TS.2020/6/Rev.1), Mexico City, Economic Commission for Latin America and the Caribbean (ECLAC). (2020b), "El derecho a la vida y la salud de las personas mayores en el marco de la pandemia por COVID-19" (LC/MEX/TS.2020/9), Mexico City, Economic Commission for Latin America and the Caribbean (ECLAC)

(ed.) (2018), "Envejecimiento, personas mayores y Agenda 2030 para el Desarrollo Sostenible: perspectiva regional y de derechos humanos", ECLAC Books, No. 154 (LC/PUB.2018/24-P), Santiago, Economic Commission for Latin America and the Caribbean (ECLAC)

IACHR (Inter-American Commission on Human Rights) (2020), "IACHR Urges States to Guarantee the Rights of Older People during the COVID-19 Pandemic", Press Release, Washington, D.C., 23 April [online] https://www.oas.org/en/iachr/media_center/ PReleases/2020/088.asp.

IDB (Inter-American Development Bank) (2020a), "COVID-19 and aging" [online] https:// www.iadb.org/en/panorama/covid-19-and-aging. (2020b), "Indicators: panorama of aging and long-term care" [online] https://www. iadb.org/en/panorama/indicators.

ILO (International Labour Organization) (2017), World Social Protection Report 2017-19. Universal Social Protection to Achieve the Sustainable Development Goals, Geneva.

Lloyd-Sherlock, E. and others (2020), "Bearing the brunt of COVID-19: older people in low and middle income countries", BMJ, vol. 368, London, BMJ Publishing Group, March.

México, Government of (2020a), "COVID-19 México" [online database] https://coronavirus. gob.mx/datos/.

(2020b), "Adultos mayores" [online] https://coronavirus.gob.mx/adultos-mayores/.

Nepomuceno, M. and others (2020), "Besides population age structure, health and other demographic factors can contribute to understanding the COVID-19 burden", Proceedings of the National Academy of Sciences (PNAS), vol. 117, No. 25, Washington, D.C., National Academy of Sciences (NAS).

OAS (Organization of American States) (2015), Inter-American Convention on Protecting the Human Rights of Older Persons, Washington, D.C.

OHCHR (Office of the United Nations High Commissioner for Human Rights) (2020), "COVID-19 and the rights of persons with disabilities: guidance", Geneva, 29 April [online] https://www.ohchr.org/Documents/Issues/Disability/COVID-19_and_The_ Rights_of_Persons_with_Disabilities.pdf.

PAHO (Pan-American Health Organization) (2020), COVID-19 Information System for the Region of the Americas [online database] https://paho-covid19-response-who. hub.arcgis.com/.

Promislow, D. (2020), "A geroscience perspective on COVID-19 mortality", The Journals of Gerontology, vol. 75, No. 9, Oxford, Oxford University Press.

Ritchie, H. and others (2020), "Coronavirus (COVID-19) Testing", Oxford, University of Oxford, October [online database] https://ourworldindata.org/coronavirus-testing.

Rodríguez, J. and M. Cobos (2014), "Fecundidad adolescente, unión y crianza: un nuevo escenario en América Latina", Revista Latinoamericana de Población, vol. 8, No. 15, Buenos Aires, Latin American Population Association.

Ruggles, S. and others (2017), "Integrated Public Use Microdata Series: Version 7.0 [dataset]", Minneapolis, University of Minnesota [online] https://ipums.org/projects/ ipums-usa/d010.v7.0

SENAMA (National Service for Older Adults) (2020), "Primera dama y ministro Sichel anuncian "Protección Mayor" que promueve el cuidado y contención de personas mayores", Santiago, 25 May [online] http://www.senama.gob.cl/noticias/primeradama-y-ministro-sichel-anuncian-proteccion-mayor-que-promueve-el-cuidado-ycontencion-de-per.

Tableau Public (2018), "Condiciones de salud de la población adulta mayor" [online database] https://public.tableau.com/profile/observatorio.envejecimiento\#!/ vizhome/g_salud/dsh_salud. 
Ullmann, H., C. Maldonado and M. Nieves (2014), "Families in Latin America: changes, poverty, and access to social protection", International Journal of Sociology of the Family, vol. 40, No. 2, Tacoma, International Journals

UNFPA (United Nations Population Fund) (2020), "Implications of COVID-19 for older persons: responding to the pandemic", UNFPA Global Technical Brief, New York, April.

United Nations (2020a), Progress towards the Sustainable Development Goals: Report of the Secretary-General (E/2020/57), New York, April. (2020b), Policy Brief: The Impact of COVID-19 on Older Persons, New York, May. (2019a), World Population Prospects 2019 [online database] https://population. un.org/wpp/Download/Standard/Population/.

(2019b), World Population Prospects 2019: Highlights (ST/ESA/SER.A/423), NewYork. (2019c), Database on the Households and Living Arrangements of Older Persons 2019 [online] https://population.un.org/LivingArrangements/index.html. (2019d), "Living arrangements of older persons around the world", Population Facts, No. 2019/2, New York, April.

(2015), Transforming our world: the 2030 Agenda for Sustainable Development (A/ RES/70/1), New York.

(2003), Political Declaration and Madrid International Plan of Action on Ageing, New York.

WHO (World Health Organization) (2020a), COVID-19 Strategy Update, Geneva, 14 April [online]https://www.who.int/publications-detail/covid-19-strategy-update---14april-2020.

(2020b), "Mental health and psychosocial considerations during the COVID-19 outbreak", Geneva, 18 March [online] https://www.who.int/docs/default-source/ coronaviruse/mental-health-considerations.pdf.

(2020c), "Infection prevention and control guidance for long-term care facilities in the context of COVID-19: interim guidance", Geneva, 21 March [online] https://apps. who.int/iris/bitstream/handle/10665/331508/WHO-2019-nCoV-IPC_long_term_care2020.1-eng.pdf.

(2020d), "Water, sanitation, hygiene, and waste management for SARS-CoV-2, the virus that causes COVID-19: interim guidance", Geneva, 29 July [online] https://www. who.int/publications/i/item/water-sanitation-hygiene-and-waste-managementfor-covid-19

(2020e), Strengthening Preparedness for COVID-19 in Cities and Other Urban Settings: Interim Guidance for Local Authorities, Geneva.

(2020f), Disability Considerations during the COVID-19 Outbreak, Geneva. (2020g), "Information note: COVID-19 and NCDs", Geneva [online] https://www. who.int/publications/m/item/covid-19-and-ncds. (2015), World Report on Ageing and Health, Geneva.

This document is one of a series of reports prepared by the Economic Commission for Latin America and the Caribbean (ECLAC) on the COVID-19 pandemic and its effects in Latin America and the Caribbean. It was prepared by the Latin American and Caribbean Demographic Centre (CELADE)-Population Division of ECLAC, directed by Paulo Saad, under the overall coordination of Alicia Bárcena, Executive Secretary of ECLAC.

This report was made possible by funding from the Federal Ministry for Economic Cooperation and Development and the German Agency for International Cooperation (GIZ) of the Government of Germany.

The boundaries and names shown on the maps included in this publication do not imply official endorsement or acceptance by the United Nations.

Copyright (C) Naciones Unidas, 2020 